\title{
Geophysical Investigation of Shallow Subsurface Fracture Distribution in Parts of the Eastern Basement Complex of Nigeria
}

\author{
George, A. Michael ${ }^{1}$, Okwueze, E. E ${ }^{1}$, and Abong, A. Agwul ${ }^{2}$ \\ 1 Department of Physics University of Calabar-Nigeria \\ 2 Department of Physics Cross River University of Technology, Calabar-Nigeria
}

\begin{abstract}
Very low frequency electromagnetic method was carried out at twenty three (23) locations within Parts of the Eastern Basement Complex of Nigeria. The field data were collected using ABEM Wadi VLF (very low frequency) electromagnetic instrument with other accessories. A transmitter located at Cutler, Maine USA, designated as NAA with $24.0 \mathrm{KHz}$ frequency and $1000 \mathrm{Kw}$ transmission power was used throughout the data collection exercise. The profiles were of lengths between $120 \mathrm{~m}$ and $650 \mathrm{~m}$. The station interval along each profile was $5 m$ with profile lines oriented in $N-S$, and $E-W$ directions. Data were analyzed using KHFFILT software. The results of the study showed that majority of the fractures were oriented in the $N E-S W$ direction, followed by fractures oriented in the NW-SE direction indicating that the study area is well fractured and has good potentials for ground water.
\end{abstract}

Key word: ABEM Wadi, Basement, fracture, groundwater, Very low frequency.

\section{Introduction}

The shortage of portable water supply in most parts of the crystalline bedrock environments of Southeastern Nigeria has attracted the attention of not only the researchers but also the general public. This shortage is due to collapse of many public water systems in most communities, and increasing demand resulting from increase in agricultural activities in these communities. Borehole yield is generally low in the eastern basement complex where this research is carried out. Due to this low yield, during dry season, water supplies from boreholes do not have long-term sustainability, so it is imperative to locate boreholes within the fractured and/or faulted basement rocks that are ubiquitous in this area. Detecting the location of these structures is often difficult if the appropriate geophysical methods are not used, consequently most boreholes drilled in these areas are either unproductive or sometimes have low yield.

Surface geophysical methods are the most rapid, inexpensive and widely used methods in geophysical surveys. Direct current resistivity method has been used by many researchers [11], [4] and has been proven successful on depth estimation, ground water potential and in hydrogeological estimation. The imaging technique is particularly powerful and useful in the study of areas of complex geology, in groundwater problems and in many other shallow subsurface investigations [3].

Research has shown that suitably sited boreholes that penetrate fracture zones have sustainable high productivity [15]; [10]; [9]; [13]. Resistivity surveys are also commonly used to map fracture zones in hard rock terrain [1] and [2] because high resistivity contrasts usually occur between solid rocks and saturated fracture zones. It has also been revealed that the success of borehole siting in this kind of environment depends on the borehole intersecting some fracture zone in the bedrock. Once the bedrock is covered by any thickness of weathering, the fracture zone may be difficult to find, in which case geophysics provides the solution to the problem [8].

\subsection{Location and Geology of Study Area}

The study area is situated within the Oban Massif located between latitudes $5^{\circ} 00^{\prime}$ and $50^{\circ} 50^{\prime} \mathrm{N}$ and longitudes $8^{\circ} 00^{\prime} \mathrm{E}$ and $8^{\circ} 50^{\prime} \mathrm{E}$. Specifically, the study area lies between latitudes $5^{\circ} 15^{\prime} \mathrm{N}$ and $5^{\circ} 27.5^{\prime} \mathrm{N}$ and longitudes $8^{\circ} 15^{\prime} \mathrm{E}$ and $8^{\circ} 25^{\prime} \mathrm{E}$ (Fig.1). It covers an area of $198.125 \mathrm{sq} . \mathrm{km}$. The study area lies within the tropical rain forest of Nigeria with two distinct seasons: wet season, which is between March and October and dry season which starts in November and ends in March. The mean temperature in the study area is about $30^{\circ} \mathrm{C}$ with a mean annual rainfall of about $2300 \mathrm{~mm}$ with annual daily relative humidity and evaporation of $80 \%$ and 3.85 $\mathrm{mm} /$ day respectively [14].

Geologically, Oban Massif is a Precambrian basement complex located in Southeastern Nigeria surrounded by cretaceous and young sedimentary rocks. Lithologically, three major rock groups are recognized in this region and are migmatitic and sheared gneissic rocks, older granite intrusive and unmetamorphosed dolerite to microdolerite intrusive (Fig.2). 
The Oban Massif is made up of two main sectors namely, the western sector (topographically sub-dued with population density) and the eastern sector (topographically rugged country with peaks forested up to summits and sparse human settlements [5]. The Oban massif is underlain by highly deformed Precambrian crystalline rocks, mainlygranites, gneisses and schist. These rocks exhibit varying degrees of weathering across the massif. They are intruded by pegmatite, granodiorites, diorites, tonolites, monzonites, charnokites and dolerites [7]. The Oban Massif has a complex lithology and the differentiation of the rock types is difficult. One of the difficulties is due to the location of Oban Massif which is in the thick equatorial rainforest inhibited by wildlife. More so, rock outcrops in the area are generally intensely weathered thus making it difficult to see fresh rock for geological studies [6]. In terms of the rock ages, the oldest is the banded gneisses while diorite is the youngest rock in the Oban Massif.
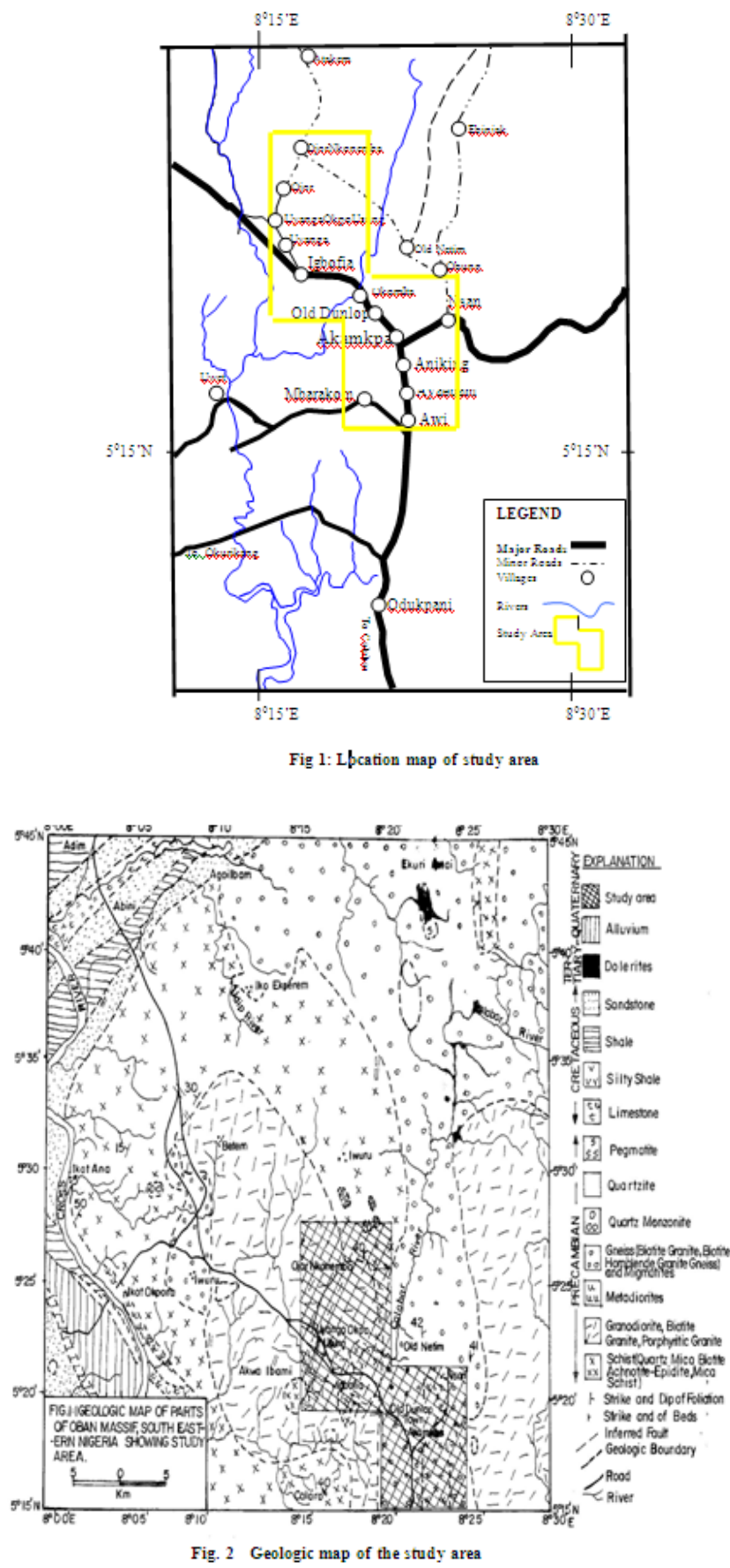


\section{Materials and method}

A total of twenty-three (23) profile lines were covered scattered throughout the surveyed area using ABEM Wadi VLF instrument with other accessories. A transmitter located at Cutler, Maine USA, designated as NAA with $24.0 \mathrm{KHz}$ frequency and $1000 \mathrm{Kw}$ transmission power was used throughout the data collection exercise. The profiles were of lengths between $120 \mathrm{~m}$ and $650 \mathrm{~m}$. The station interval along each profile was $5 \mathrm{~m}$ with profile lines oriented in $\mathrm{N}-\mathrm{S}$, and $\mathrm{E}-\mathrm{W}$ directions respectively. The location of each profile line is as shown is Fig. 3.

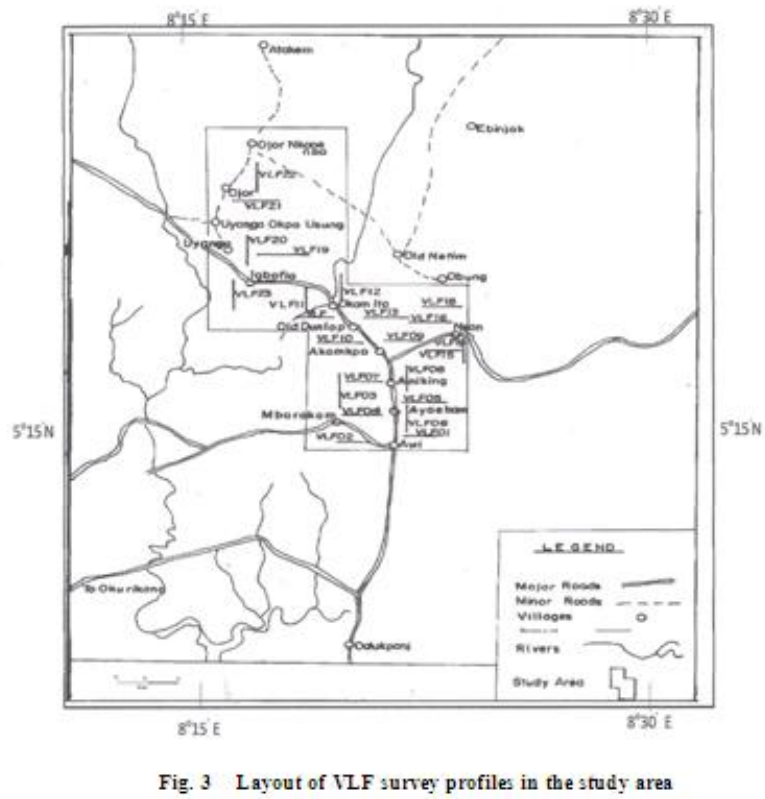

Along each profile, measurements were made for in-phase and quadrature values respectively, but the in-phase data was used for the interpretation as prescribed by the software used for the interpretation. The profiles are denoted as VLF 01 to VLF 23

\section{Data analysis}

VLF (very low frequency) datawere analyzed and processed by plotting the percentage in-phase (real) component data against the sample point distances for both the raw field measured data and the filtered data using KHFFILT software. The KHFFILT program was also used to perform Karous-Hjelt and Fraser filtering on the field data. Lower values of relative current density correspond to higher values of resistivity and low conductivity while higher values of relative current density correspond to lower values of resistivity and high conductivity. The conductive targets were denoted with positive Fraser and Karous-Hjelt anomalies. The European convention of using red color for conductive (hot) targets was employed in the pseudo section plot [12].

\section{Results and discussion}

Interpretation of the data along these VLF traverses indicates both positive and negative Fraser and Karous-Hjelt anomalies an indication of a probable fracture zones along each of the traverses. For each sample point, a plot of the raw field data, the Fraser filtered data and the Karous-Hjelt plots are displayed. At location VLF01, both the raw in-phase and the filtered data were plotted (Fig. 4 and Fig. 5). Positive Fraser filter responses were observed between $10-30 \mathrm{~m}$ and between $50-70 \mathrm{~m}$ along the traverse (Fig. 5). These correspond to probable fracture zones of depth between $0-20 \mathrm{~m}$ and $0-25 \mathrm{~m}$ oriented in the NW $-\mathrm{SE}$ and $\mathrm{N}-\mathrm{S}$ directions respectively (Fig. 6). 


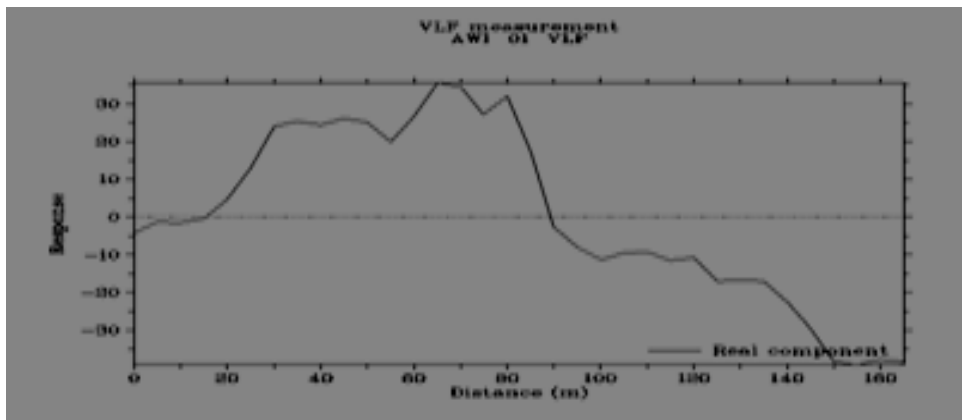

Fig. 4: A plot of unfiltered in-phase data against distance at location VLF 01

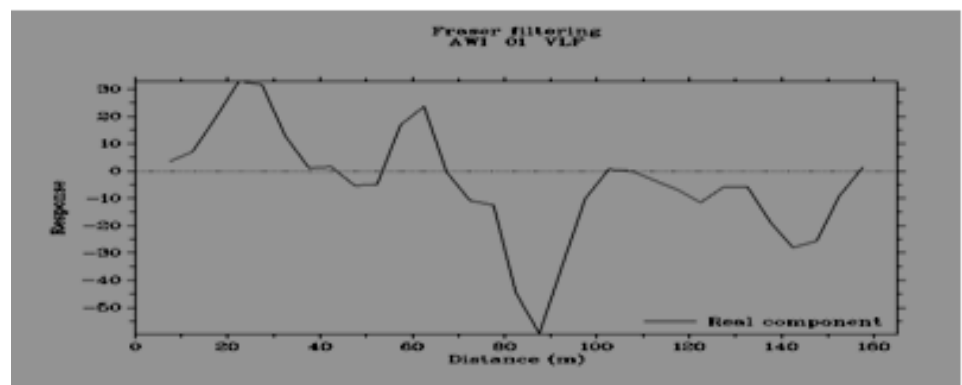

Fig. 5: A plot of filtered in-phase data against distance at location VIF 01

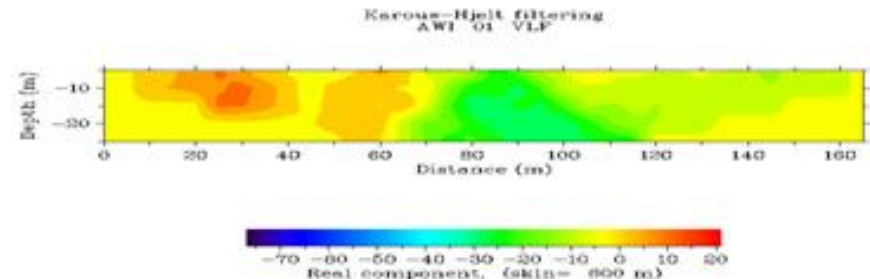

Fig. 6: Current density cross section plot of in-phase data against distance at location VLF 01

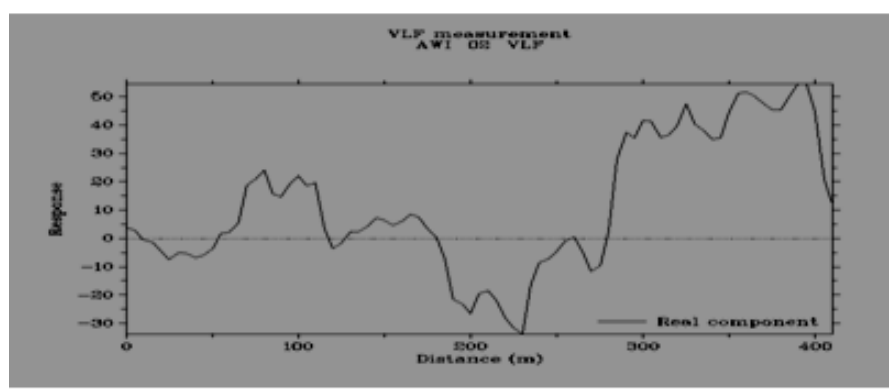

Fig. 7: A plot of unfiltered in-phase data against distance at location VLF 02

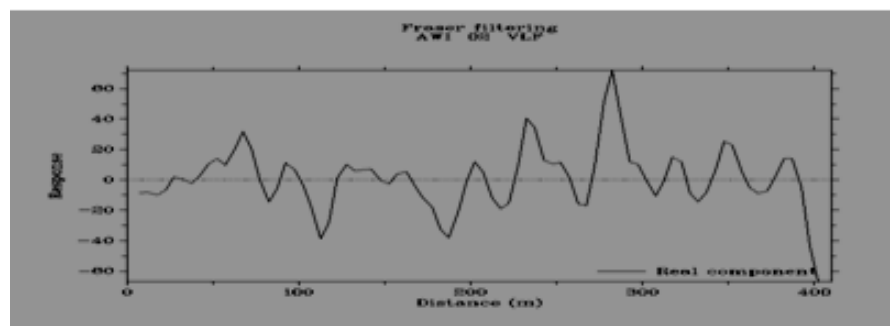

Fig. 8: A plot of filtered in-phase data against distance at location VLF 02 


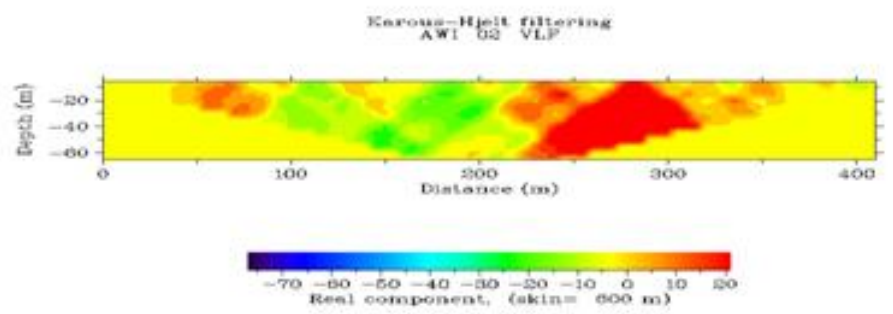

Fig. 9: Current density cross section plot of in-phase data against distance at location VLF 02

At location VLF 02, both raw field VLF data (Fig.7) and filtered VLF data (Fig.8) were plotted. Prominent positive Fraser filter response was observed from the plot (Fig.18) between 50-80m, $230-260 \mathrm{~m}$, $270-300 \mathrm{~m}$ and $340-360 \mathrm{~m}$ respectively. These correspond to a probable fracture zone at a depth extending from $0-25 \mathrm{~m}$ oriented $\mathrm{NW}-\mathrm{SE}$ and another of depth extending from zero to over $65 \mathrm{~m}$ oriented at $\mathrm{NE}-\mathrm{SW}$ direction (Fig.9).

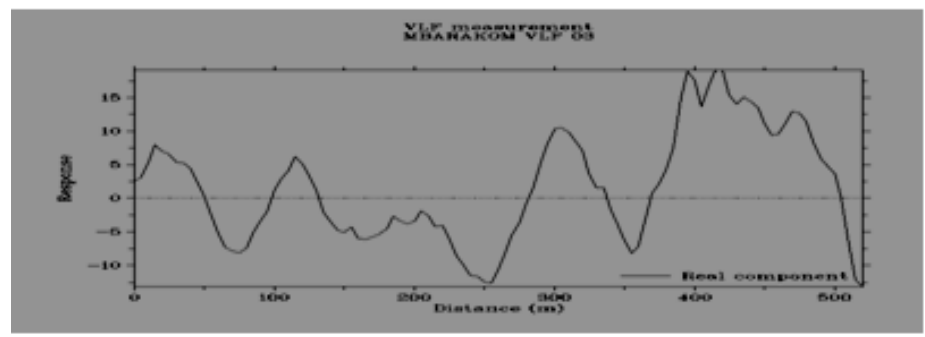

Fig. 10: A plot of unfiltered in-phase data against distance at location VLF 03

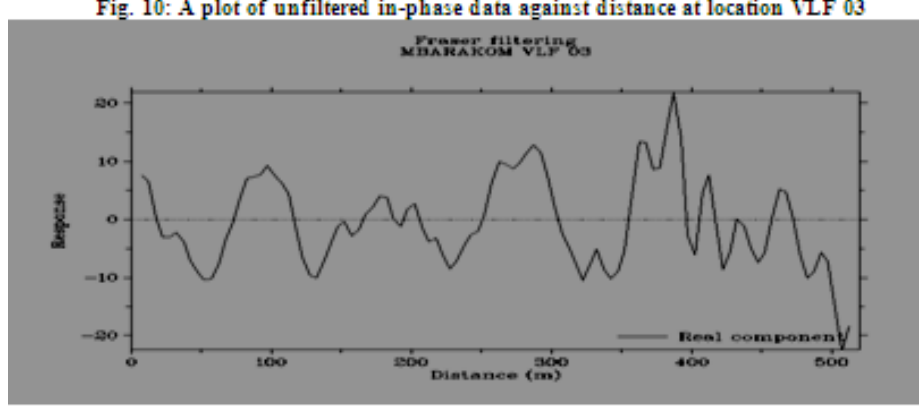

Fig. 11: A plot of filtered in-phase data against distance at location VLF 03

Karsü
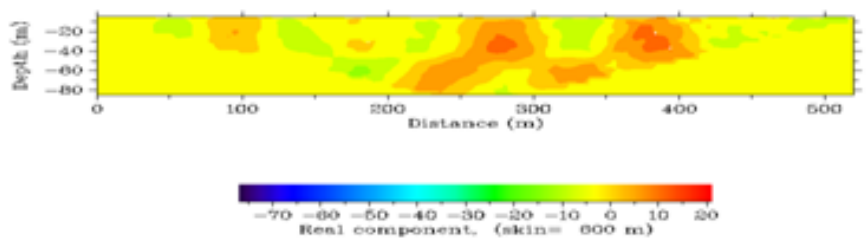

Fig. 12: Current density cross section plot of in-phase data against distanceat location VIF 03

The raw VLF data Figure 10 and filtered VLF data (Fig.11) collected at location VLF 03 were plotted and three fracture zones with positive Fraser filter response was identified (Fig.12). These zones are located at a horizontal distance of between $80-120 \mathrm{~m}, 250-300 \mathrm{~m}$ and $350-400 \mathrm{~m}$ along the traverse. These correspond to a probable fracture zones at a depth of between $0-40 \mathrm{~m}, 0-80 \mathrm{~m}$ and $0-60 \mathrm{~m}$ respectively. These zones were oriented at $\mathrm{E}-\mathrm{W}$ and $\mathrm{NW}-\mathrm{SE}$ respectively (Fig.12). 


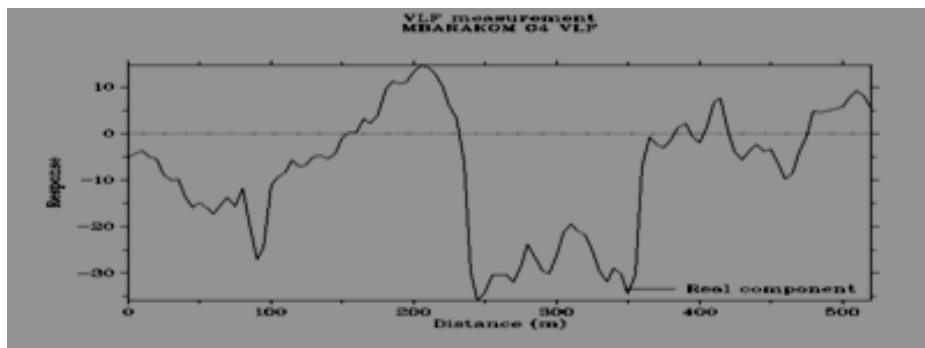

Fig. 13: A plot of unfiltered in-phase data against distance at location VLF 04

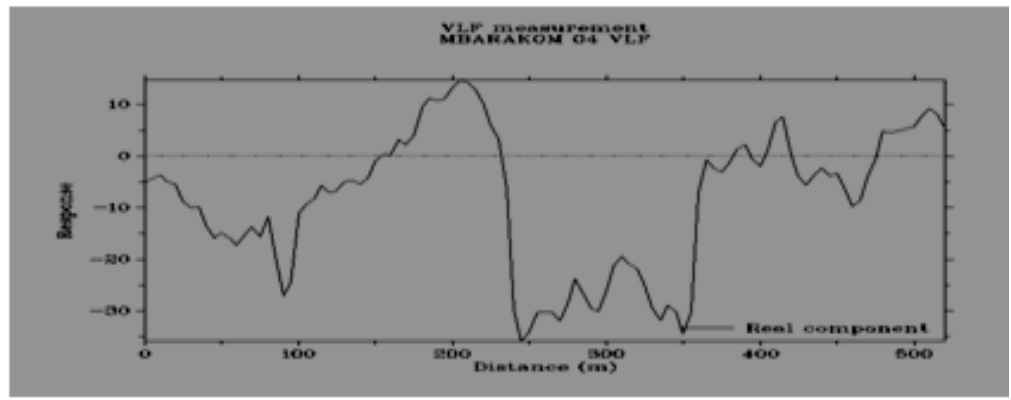

Fig. 14: A plot of filtered in-phase data against distance at location VLF 04

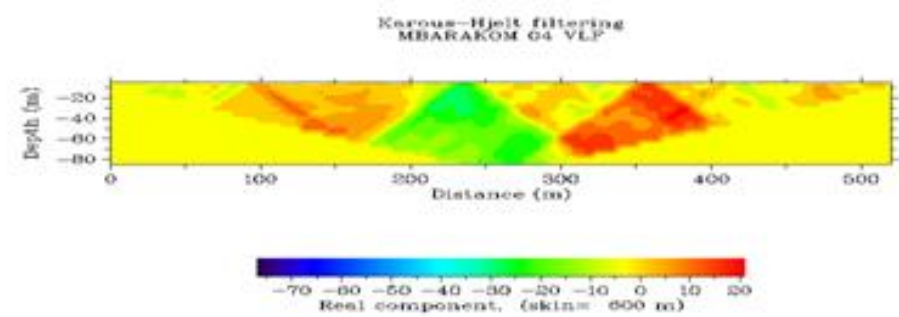

Fig.15: Current density cross section plot of in-phase data against distance at location VLF 04

At location VLF 04, Fig. 13 shows a plot of the raw VLF data, many positive Fraser filter responses were noticed along the traverse. Two of which were prominent and were located between $100-120 \mathrm{~m}$ and $350-370 \mathrm{~m}$ ( Fig.14), giving rise to probable fracture zones at depth extending from $0-60 \mathrm{~m}$ and $0-80 \mathrm{~m}$ respectively. These fracture zones (Fig.15) were oriented at NW - SE and NE - SW direction respectively.

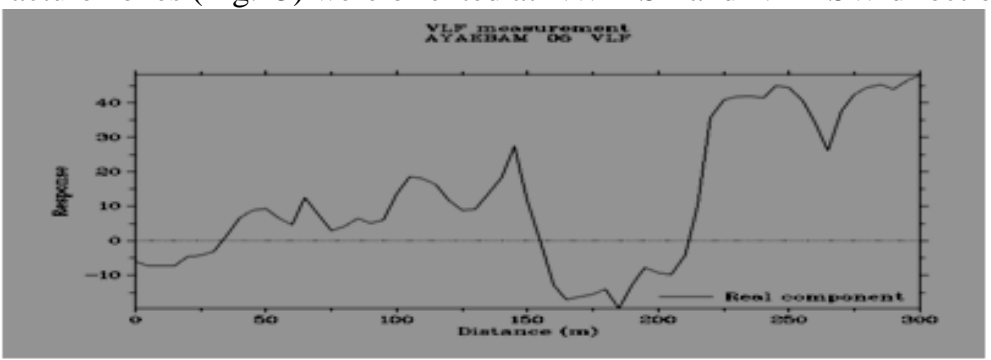

Fig. 16: A plot of unfiltered in-phase data against distance at location VLF 05

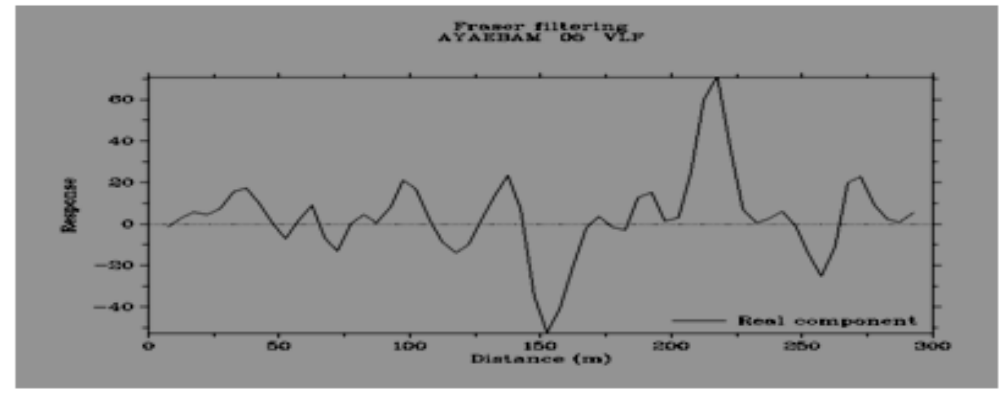

Fig. 17: A plot of filtered in-phase data against distance at location VLF 05 


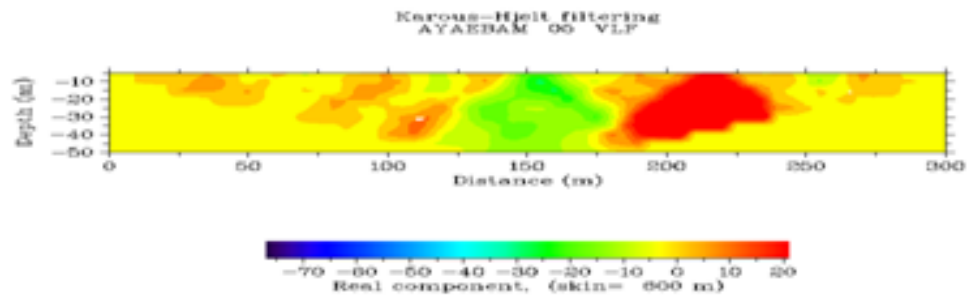

Fig.18: Current density cross section plot of in-phase data against distance at location VLF 05

At location VLF 05, (Fig.16) shows a plot of the raw field data while (Fig.17) shows a plot of the filtered VLF data, five (5) probable fracture zones were identified with one highly conductive. They were located between

$25-50 \mathrm{~m}, 75-100 \mathrm{~m}, 125-145 \mathrm{~m}, 200-225 \mathrm{~m}$ and $265-285 \mathrm{~m}$ respectively. The depth to each fracture zones was between $0-25 \mathrm{~m}, 0-30 \mathrm{~m}, 0-45 \mathrm{~m}, 0-50 \mathrm{~m}$ and $0-20 \mathrm{~m}$ respectively. Their orientations were NW - SE, NE - SW, NE - SW, NE - SW and NE - SW respectively (Fig.18).

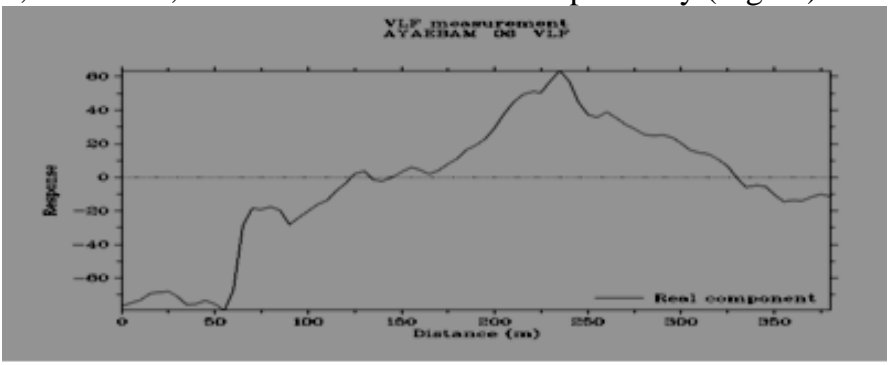

Fig. 19: A plot of unfiltered in-phase data against distance at location VLF 06

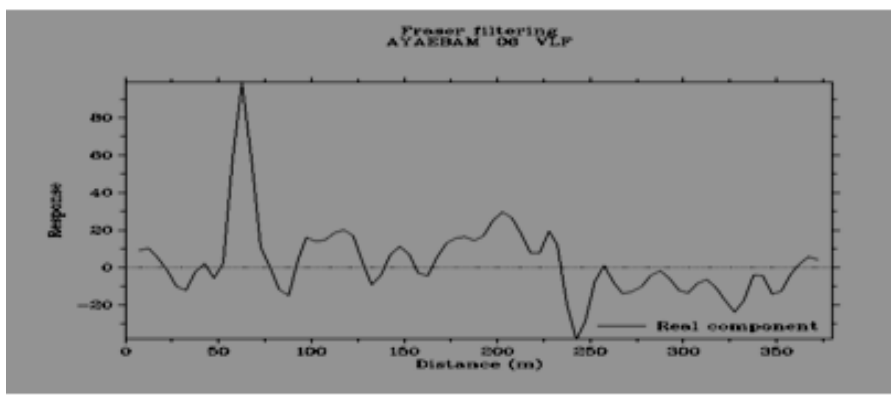

Fig. 20: A plot of filtered in-phase data against distance at location VLF 06

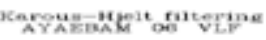

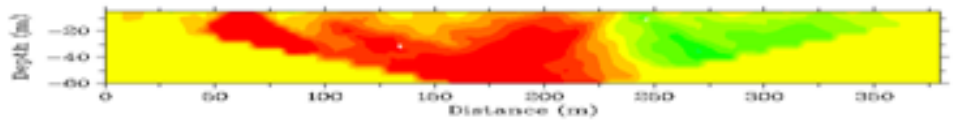

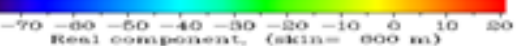

Fig. 21: Current density cross section plot of in-phase data against distance at location VIF 06

The result of VLF data collected at location VLF 06 (Fig. 20) and (Fig. 21) shows four (4) positive Fraser filter responses along the horizontal position between $50-75 \mathrm{~m}, 95-125 \mathrm{~m}, 145-155 \mathrm{~m}$ and $175-225 \mathrm{~m}$ respectively. These correspond to a probable co-joint fracture zone at a depth extending from zero to $60 \mathrm{~m}$ oriented at NE - SW direction as shown in (Fig.31). 


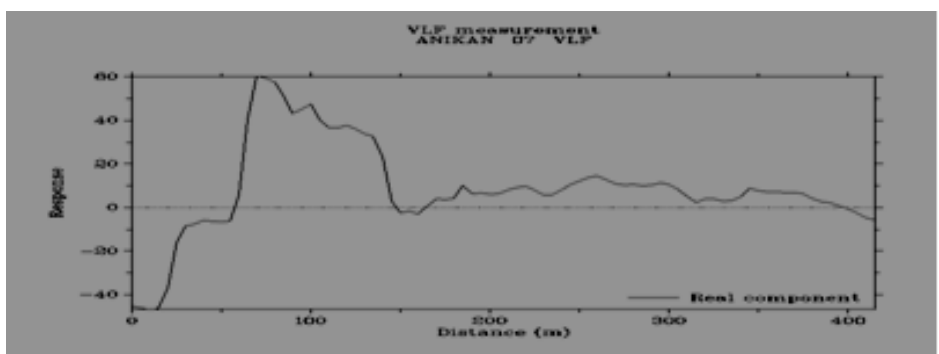

Fig. 22: A plot of unfiltered in-phase data against distance at location VLF 07

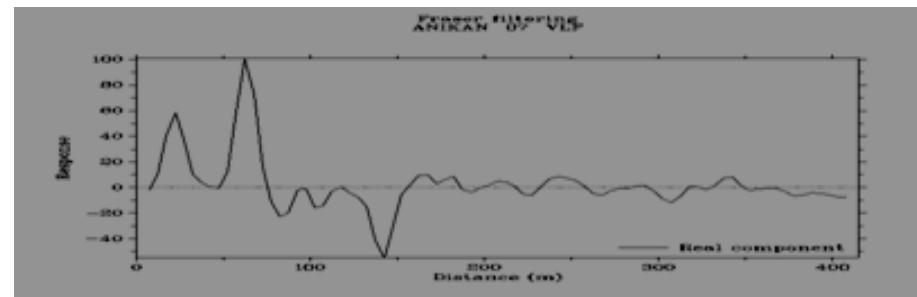

Fig. 23: A plot of filtered in-phase data against distance at location VLF 07

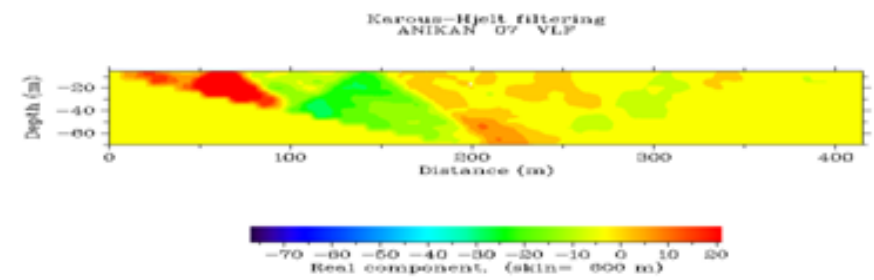

Fig. 24: Current density cross section plot of in-phase data against distance at location VLF 07

Fig. 22 and Fig. 23 show a plot of both raw and filtered VLF response against distance at location VLF 07. The plot shows two (2) prominent Positive Fraser filter responds between $10-40 \mathrm{~m}$ and $50-75 \mathrm{~m}$. These correspond to probable fracture zones located between $10-75 \mathrm{~m}$ along the horizontal axis at a depth extending from $0-40 \mathrm{~m}$ from the surface and oriented at NW - SE direction as shown in (Fig.24).

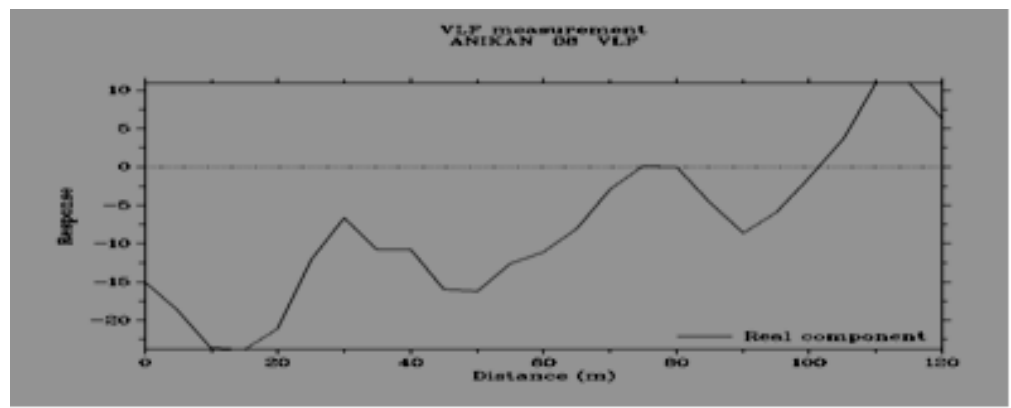

Fig. 25: A plot of unfiltered in-phase data against distance at location VIF 08

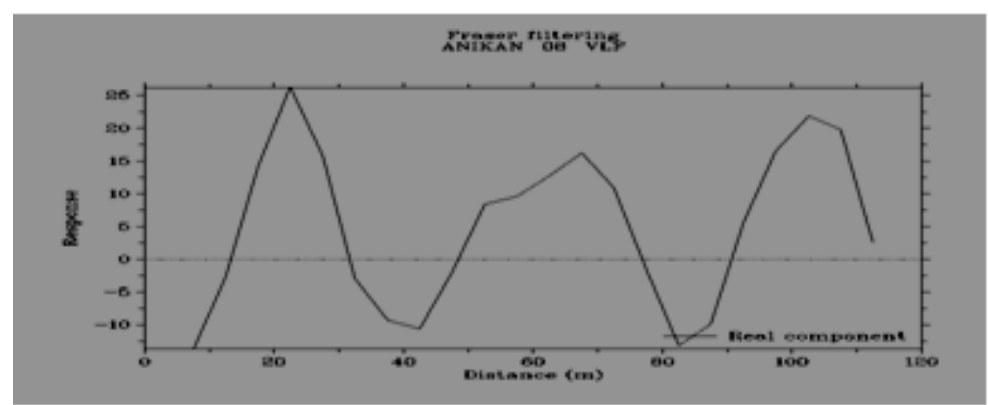

Fig. 26: A plot of filtered in-phase data against distance at location VLF 08 


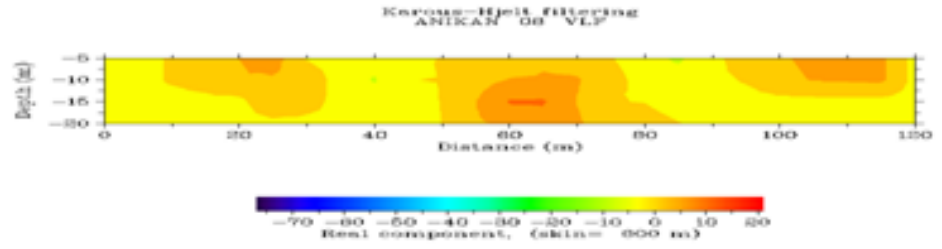

Fig. 27: Current density cross section plot of in-phase data against distance at location VIF 08

At location VLF 08, both raw VLF data Figure 25 and filtered data Figure 26 were plotted. Positive Fraser filter responses were observed between $12-34 \mathrm{~m}, 50-78 \mathrm{~m}$ and $90-115 \mathrm{~m}$ along the traverse Figure 26 . These give rise to probable fracture zones located between $20-25 \mathrm{~m}, 56-70 \mathrm{~m}$, and $105-115 \mathrm{~m}$ respectively with an orientation of $\mathrm{E}-\mathrm{W}$ direction Figure 27. They zones are at a depth of $0-10 \mathrm{~m}, 10-$ over $20 \mathrm{~m}$ and $0-10 \mathrm{~m}$ respectively.

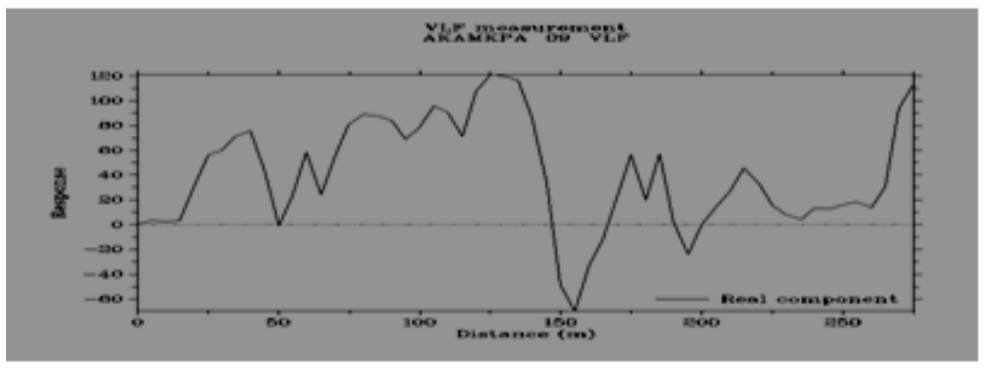

Fig. 28: A plot of unfiltered in-phase data against distance at location VLF 09

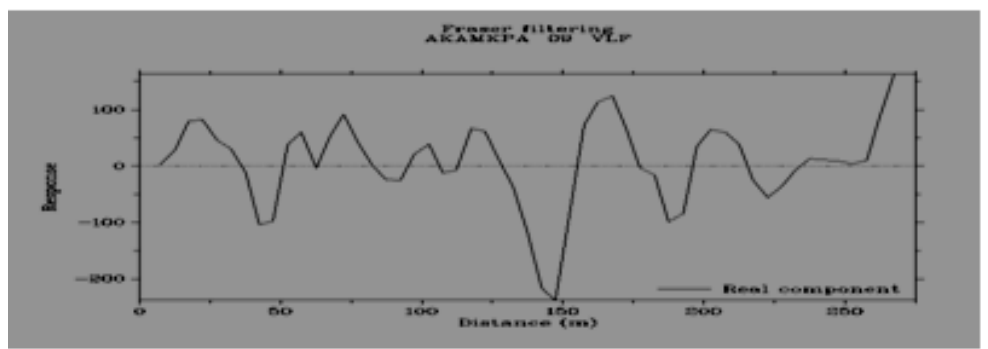

Fig. 29: A plot of filtered in-phase data against distance at location VLF 09

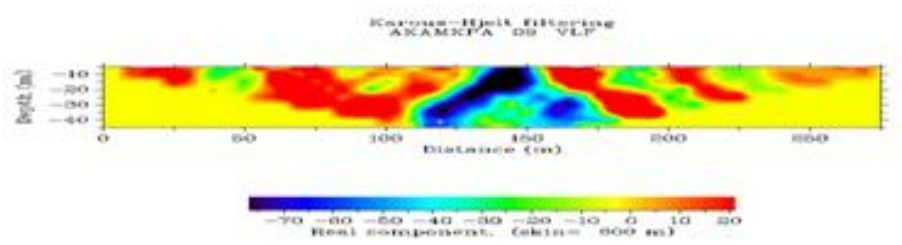

Fig. 30: A plot of filtered in-phase data against distance at location VIF 09

At location VLF 09, both raw VLF data (Fig. 28) and filtered VLF data (Fig. 29) were plotted. Seven positive Fraser filter responses were observed (Fig. 29), located between $10-35 \mathrm{~m}, 60-80 \mathrm{~m}, 95-105 \mathrm{~m}$, $115-130 \mathrm{~m}, 155-175 \mathrm{~m}, 200-220 \mathrm{~m}$ and $250-265 \mathrm{~m}$ respectively. The corresponding probable fracture zones were located between $10-35 \mathrm{~m}, 50-105 \mathrm{~m}, 155-200 \mathrm{~m}, 200-215$ and $240-275 \mathrm{~m}$ oriented at $\mathrm{N}-\mathrm{S}$, (multiple fracture with orientation NW - SE, NE - SW, NE - SW), NW - SE, NW - SE and NW - SE direction respectively. These zones were at a depth extending from $0-20 \mathrm{~m}, 0-45 \mathrm{~m}, 0-40 \mathrm{~m}, 0-30 \mathrm{~m}$ and $0-20 \mathrm{~m}$ respectively (Fig 30 ). 


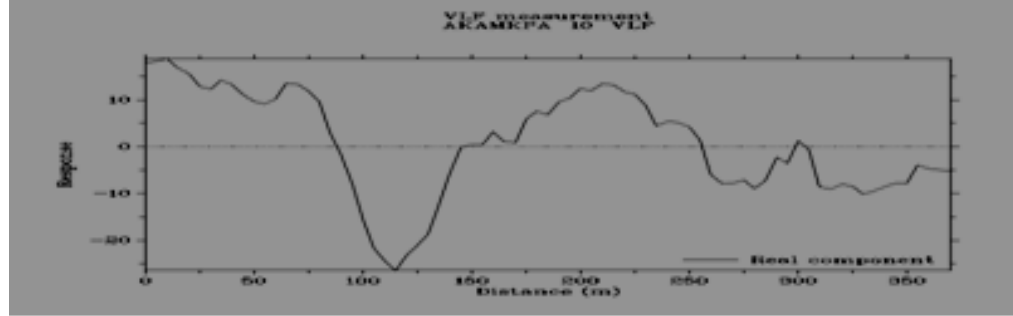

Fig. 31: A plot of unfiltered in-phase data against distance at location VLF 10

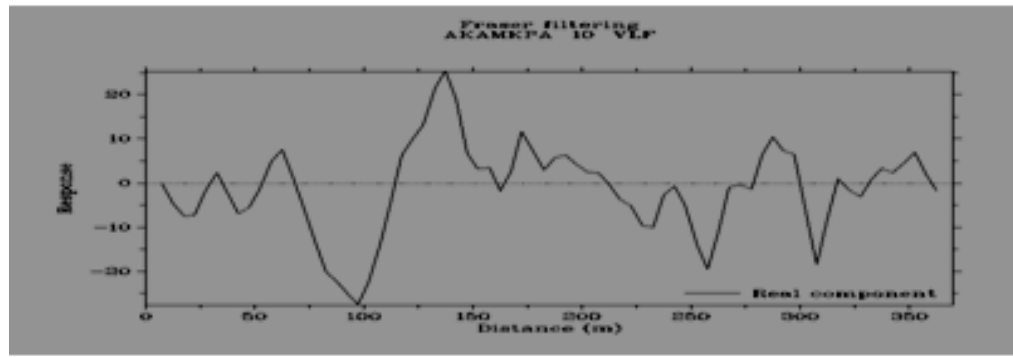

Fig. 32: A plot of filtered in-phase data against distance at location VLF 10

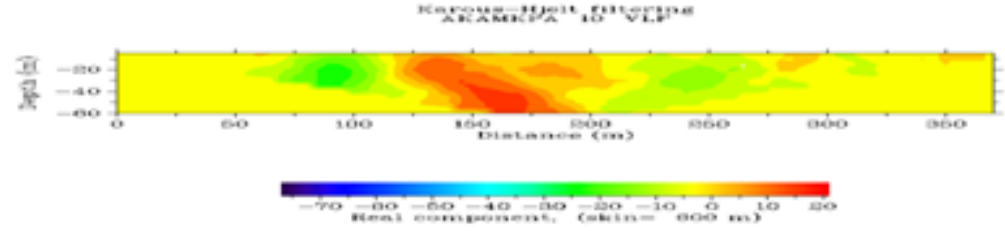

Fig. 33: Current density cross section plot of in-phase data against distance at location VIF 10

At location VLF 10, raw field VLF data (Fig.31) and filtered data (Fig.32) were plotted. Three (3) prominent positive Fraser responses were observed (Fig. 32) located between $110-200 \mathrm{~m}, 275-300 \mathrm{~m}$ and $325-360 \mathrm{~m}$ respectively. These give rise to probable fracture zones located between $125-200 \mathrm{~m}, 275-300 \mathrm{~m}$ and $350-370 \mathrm{~m}$ oriented $\mathrm{NW}-\mathrm{SE}, \mathrm{NE}-\mathrm{SW}$ and $\mathrm{N}-\mathrm{S}$ direction respectively. They were at a depth extending from 0 - over $60 \mathrm{~m}, 0-20 \mathrm{~m}$ and $0-10 \mathrm{~m}$ respectively (Fig 33 ).

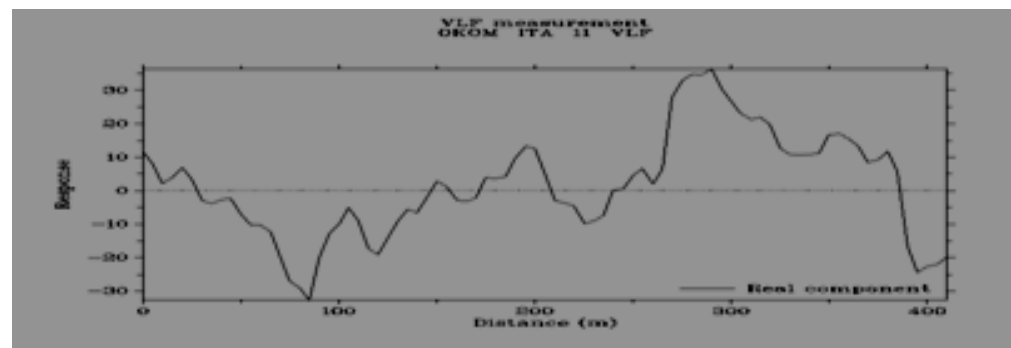

Fig. 34: A plot of unfiltered in-phase data against distance at location VLF 11

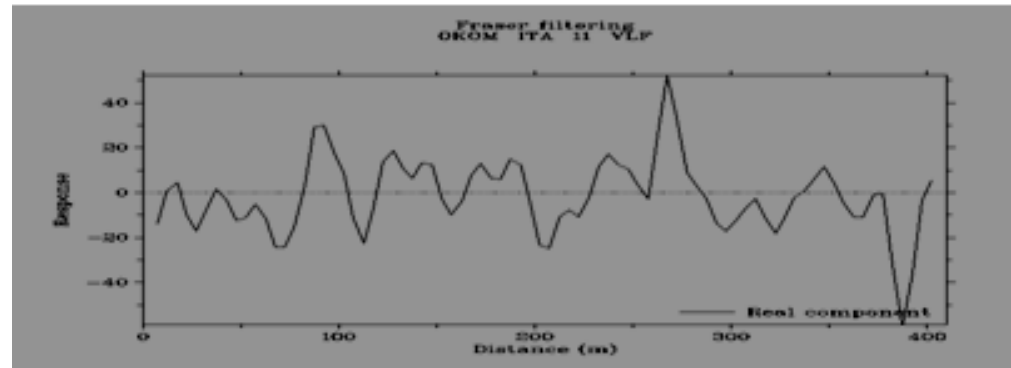

Fig. 35: A plot of filtered in-phase data against distance at location VIF 11 


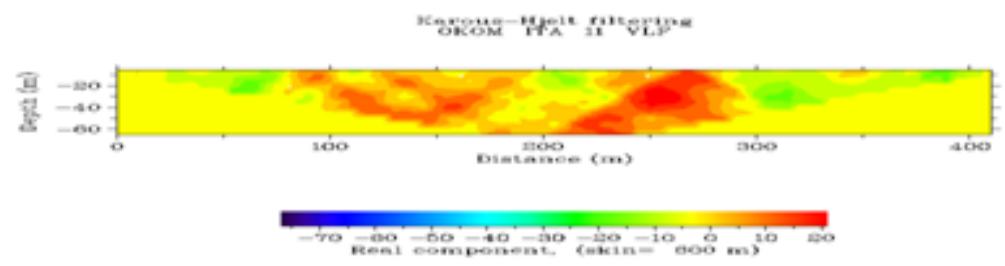

Fig. 36: Current density cross section plot of in-phase data against distance at location VLF 11

At location VLF 11, (Fig. 34) shows a plot of the raw VLF data while (Fig. 35) shows a plot of the filtered VLF data. Five (5) positive Fraser filter responses, three of which closely spaced Figure 36 were observed. These give rise to a probable fracture zones that are interconnected to each other, oriented at NE $-\mathrm{SW}$ and NW - SE respectively. They were of depth extending from $0-60 \mathrm{~m}$ and $0-$ over $60 \mathrm{~m}$ as shown in (Fig. 36).

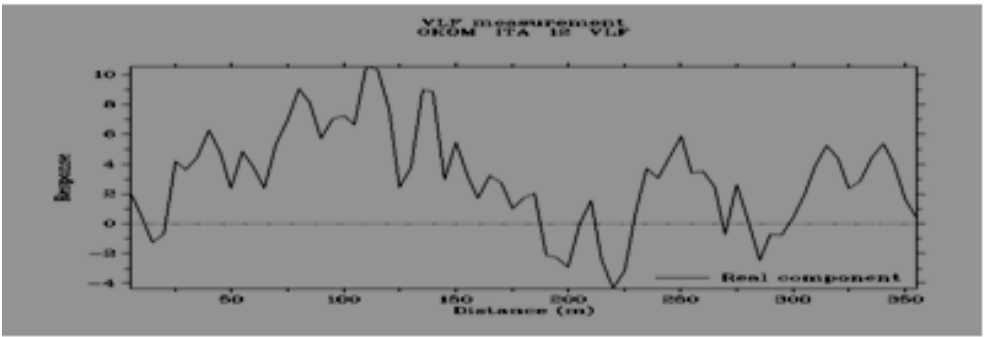

Fig. 37: A plot of unfiltered in-phase data against distance at location VLF 12

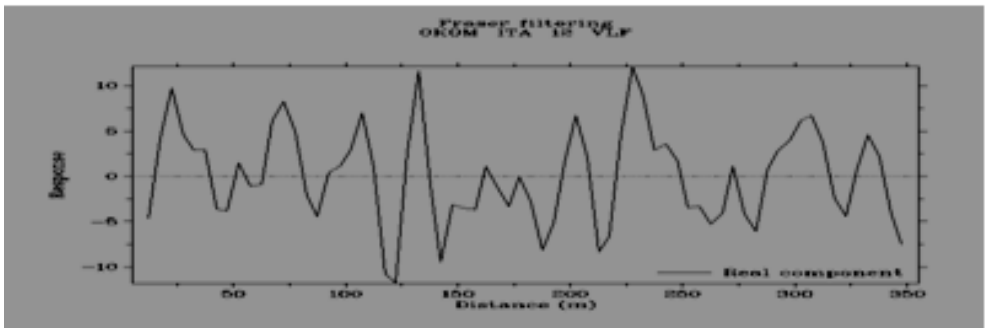

Fig. 38: A plot of filtered in-phase data against distance at location VIF 12

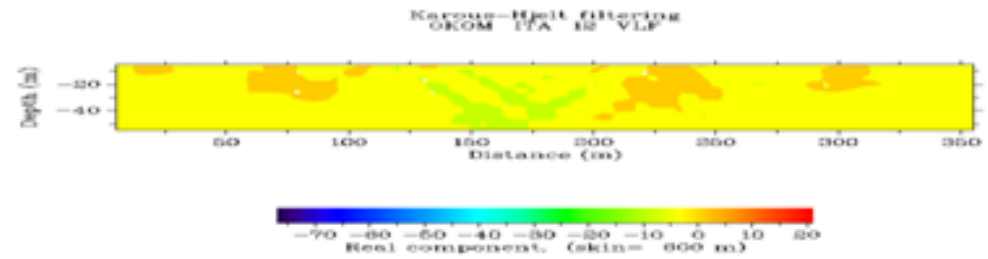

Fig. 39: Current density cross section plot of in-phase data against distance at location VIF 12

The VLF response at location VLF 12 (Fig.37) raw field data and (Fig. 38) filtered VLF data show more of positive response along the traverse resulting in a probable fracture zones located between $15-25 \mathrm{~m}$, $60-110 \mathrm{~m}, 200-250 \mathrm{~m}$ and $280-315 \mathrm{~m}$ respectively with depth extending from $0-15 \mathrm{~m}, 0-30 \mathrm{~m}, 0-15 \mathrm{~m}$, $0-40 \mathrm{~m}$ and $0-30 \mathrm{~m}$ from the surface respectively. These zones Figure 39 were oriented at $\mathrm{E}-\mathrm{W}, \mathrm{NE}-\mathrm{SW}$, $\mathrm{SE}-\mathrm{NW}$ and $\mathrm{E}-\mathrm{W}$ direction respectively. 


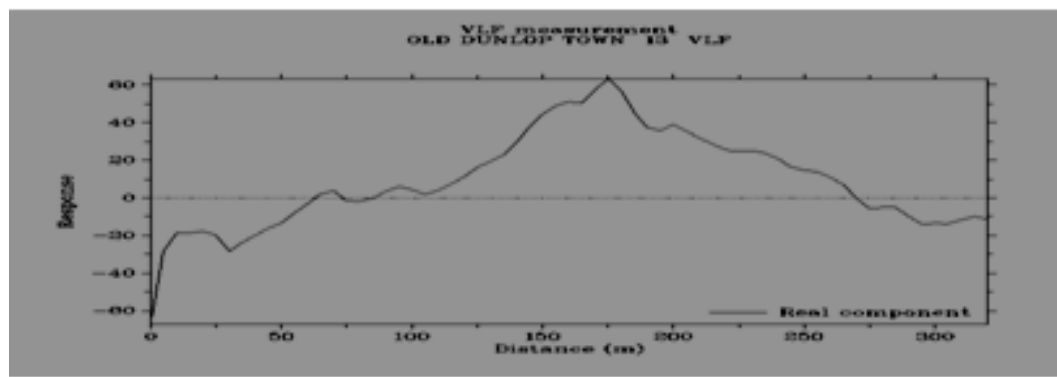

Fig. 40: A plot of unfiltered in-phase data against distance at location VLF 13

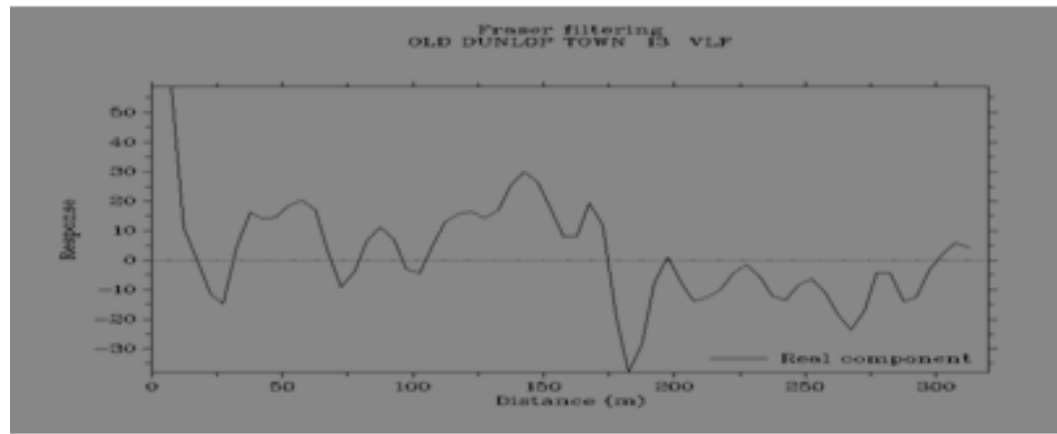

Fig. 41: A plot of filtered in-phase data against distance at location VLF 13

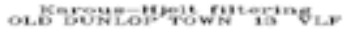

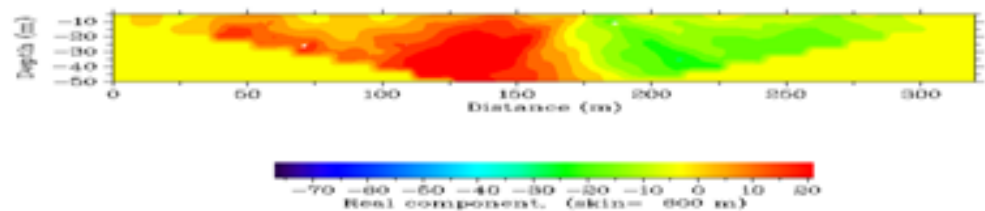

Fig. 42: Current density cross section plot of in-phase data against distance at location VLF 13

At location VLF 13, the plot of raw field data ( Fig. 40) and the filtered data ( Fig. 41) show positive response between $10-175 \mathrm{~m}$ along the traverse (Fig.41) resulting in a probable interconnection of fracture zones Figure 42 located between $10-175 \mathrm{~m}$ oriented NE - SW with depth extending from 0 - over 50m from the surface.

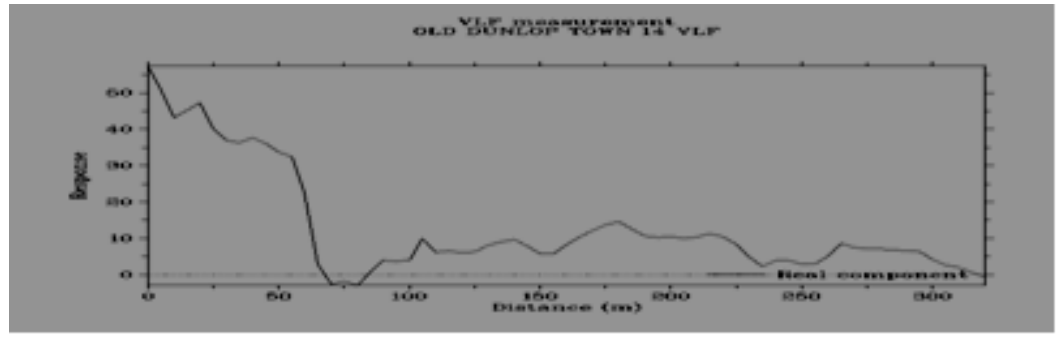

Fig. 43: A plot of unfiltered in-phase data against distance at location VLF 14

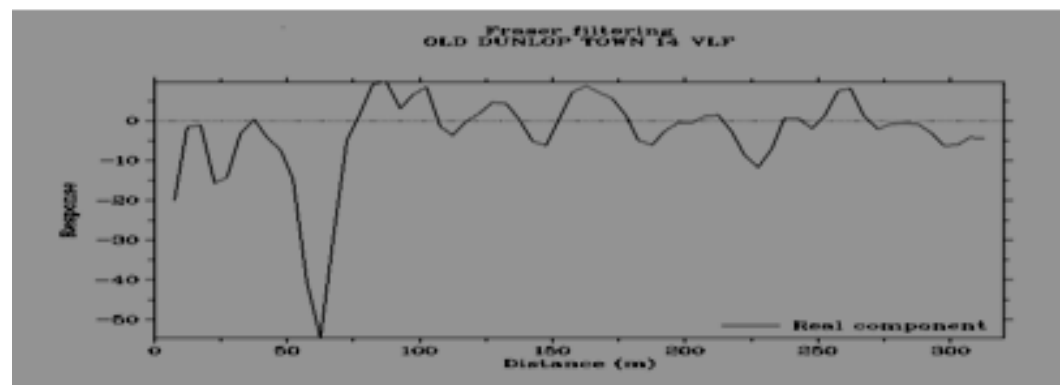

Fig. 44: A plot of filtered in-phase data against distance at location VLF 14 


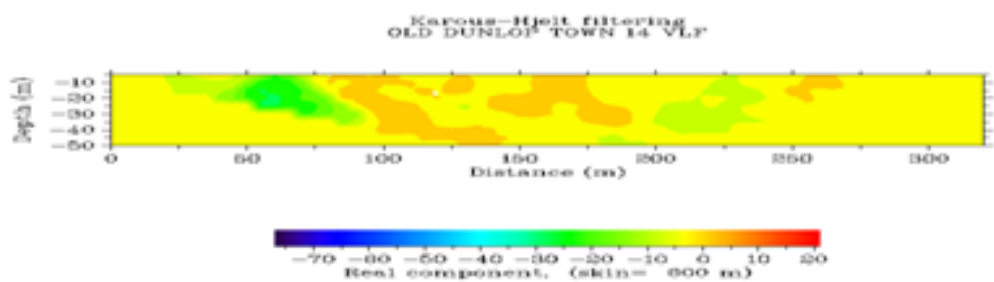

Fig. 45: Current density cross section plot of in-phase data against distance at location VLF 14

At location VLF 14, raw field data (Fig. 43) and filtered data (Fig.44) were plotted. Four (4) positive filter responses position were identified along the traverse (Fig.44), these were between $75-100 \mathrm{~m}, 115-130 \mathrm{~m}$, $150-175 \mathrm{~m}$ and $250-265 \mathrm{~m}$ respectively. The corresponding probable fracture zones were located between $80-145 \mathrm{~m}, 130-190 \mathrm{~m}$ and $250-265 \mathrm{~m}$ respectively and they were at a depth (Fig 45) extending from $0-$ over 50m, $0-20 \mathrm{~m}, 0-40 \mathrm{~m}$ and $0-20 \mathrm{~m}$ respectively, oriented at NW $-\mathrm{SE}, \mathrm{NE}-\mathrm{SW}$ and $\mathrm{NE}-\mathrm{SW}$ direction.

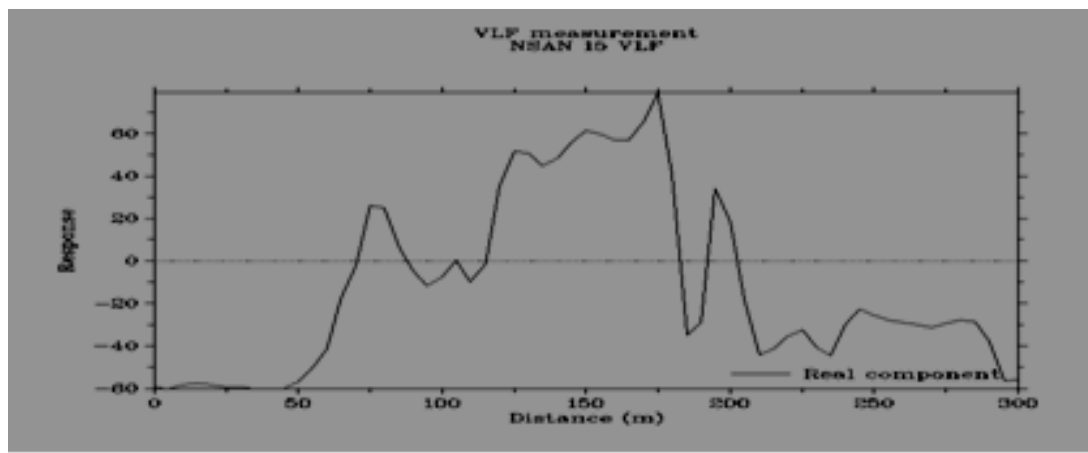

Fig. 46: A plot of unfiltered in-phase data against distance at location VLF 15

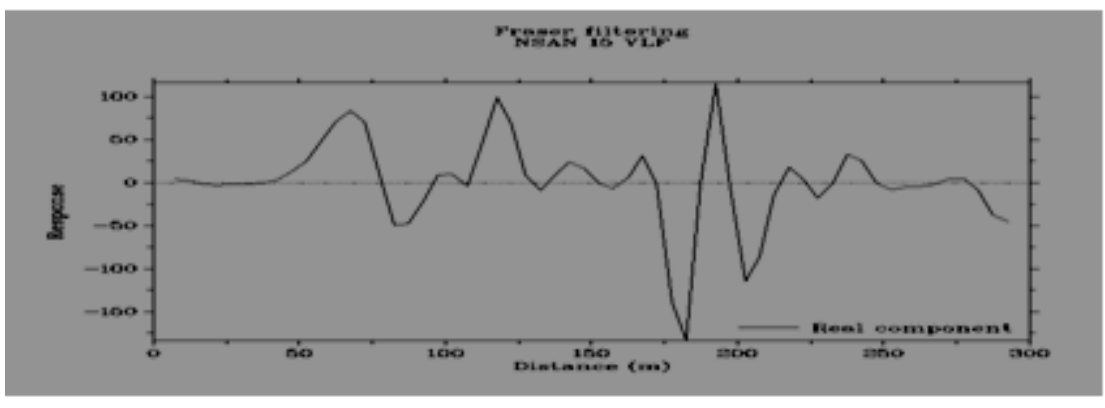

Fig. 46: A plot of unfiltered in-phase data against distance at location VIF 15

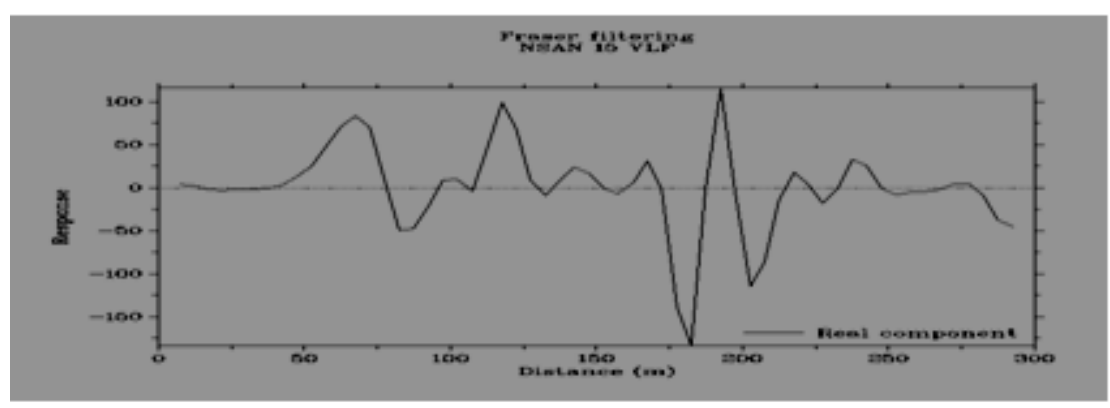

Fig. 47: A plot of filtered in-phase data against distance at location VLF 15 

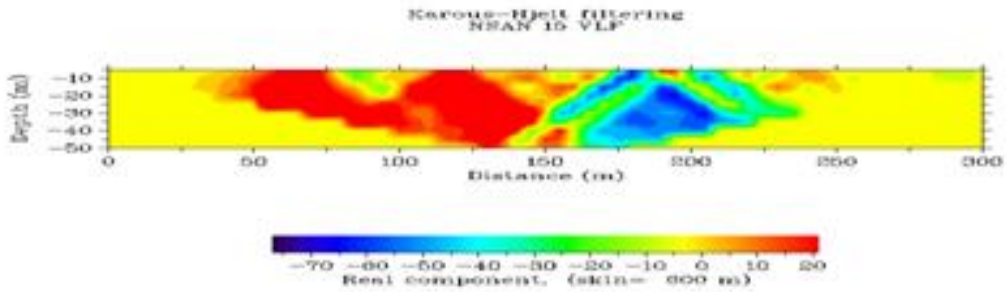

Fig. 48: Current density cross section plot of in-phase data against distance at location VIF 15

The result of VLF data collected and plotted for both raw data (Fig.46) and filtered data (Fig.47) at location VLF 15 show four (4) positive Fraser filter responses (Fig. 44) between $50-75 \mathrm{~m}, 110-125 \mathrm{~m}$,

$190-200 \mathrm{~m}$ and $230-250 \mathrm{~m}$ respectively. These result in probable interconnection of fracture zones located between $40-130 \mathrm{~m}$ oriented at NW - SE direction with depth (Fig. 48) extending from 0 - over 50m.

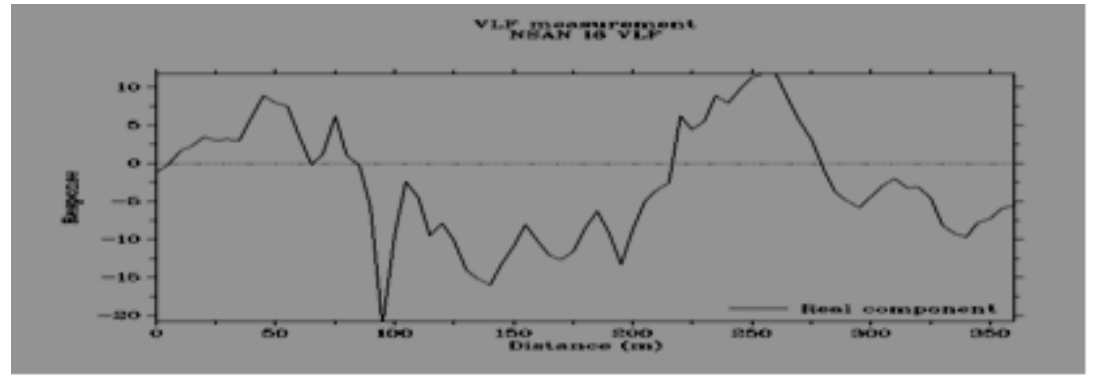

Fig.49: A plot of unfiltered in-phase data against distance at location VIF 16

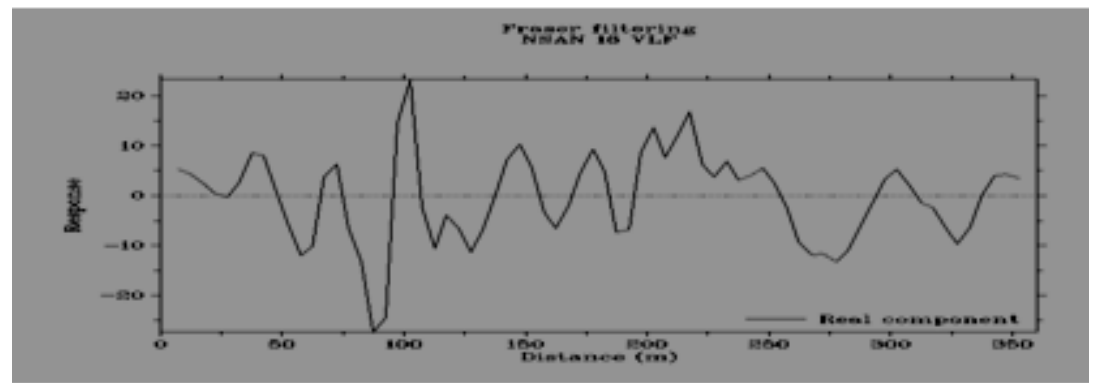

Fig. 50: A plot of filtered in-phase data against distance at location VLF 16

Karoun
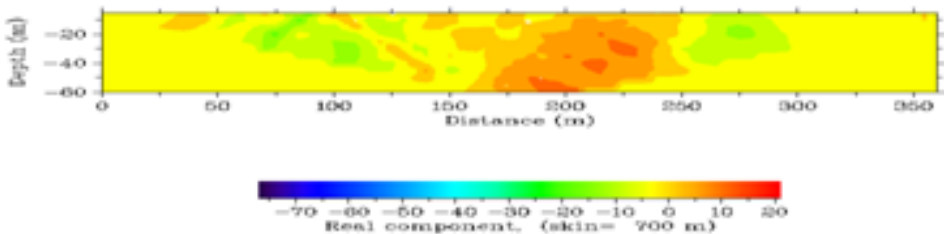

Fig. 51: Current density cross section plot of in-phase data against distance at location VIF 16

At location VLF 16, raw field VLF data (Fig.49) and filtered VLF data (Fig 50) were plotted, many positive Fraser filter responses were observed, giving rise to clusters of probable fracture zones located as shown in figure 51 at a depth extending from 0 - over $60 \mathrm{~m}$ oriented at NW - SE and NE - SW directions respectively. 


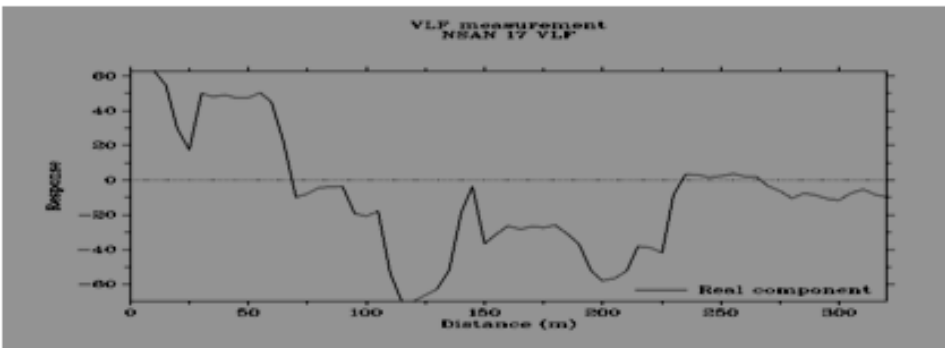

Fig. 52: A plot of unfiltered in-phase data against distance at location VLF 17

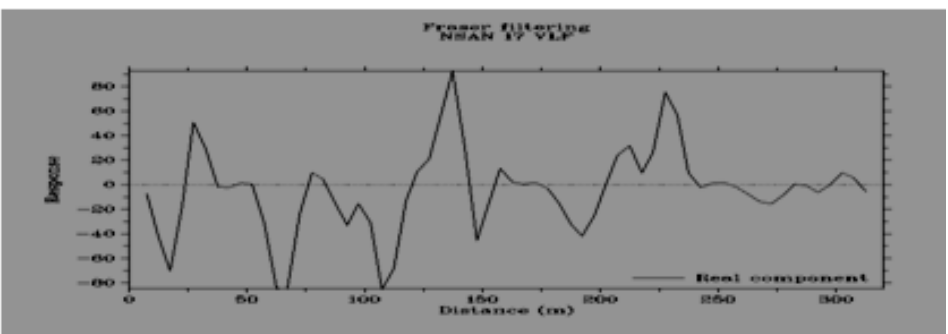

Fig. 53: A plot of filtered in-phase data against distance at location VLF 17

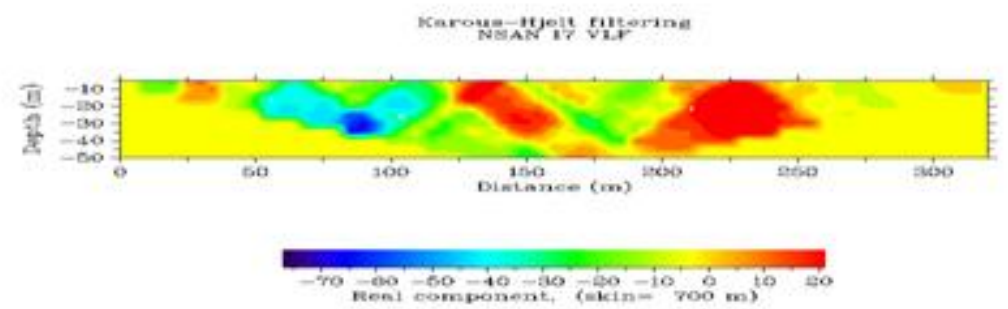

Fig.54: Current density cross section plot of in-phase data against distances at location ILF 17

The VLF data plotted for both raw data (Fig 52) and filtered data (Fig.53) at location VLF 17 show three (3) prominent positive Fraser filter responses (Fig 53) located between $25-40 \mathrm{~m}, 125-145 \mathrm{~m}$, and $200-240 \mathrm{~m}$ respectively. These results in probable fracture zones located between $25-40 \mathrm{~m}, 125-175 \mathrm{~m}$ and $190-260 \mathrm{~m}$ respectively at depth (Fig.54) extending from $0-20 \mathrm{~m}, 0-$ over $50 \mathrm{~m}$ and $0-50 \mathrm{~m}$ respectively. The orientations of these zones are $\mathrm{NW}-\mathrm{SE}, \mathrm{NE}-\mathrm{SW}$ and $\mathrm{E}-\mathrm{W}$ direction.

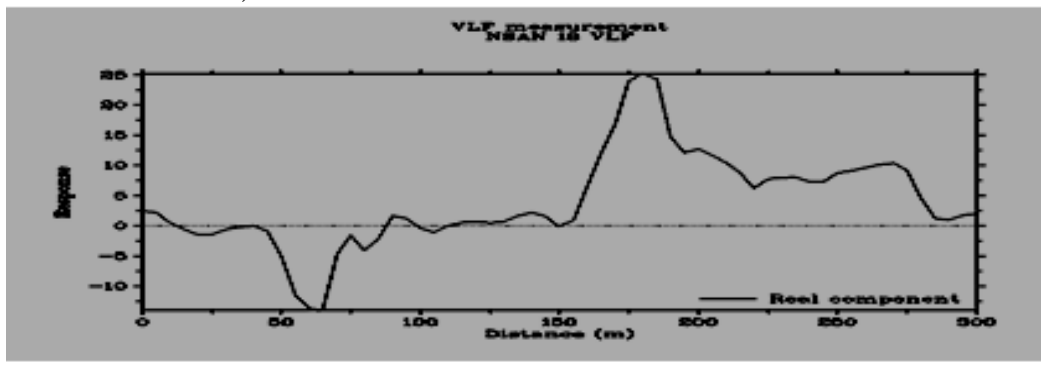

Fig. 55: A plot of unfiltered in-phase data against distance at location VIF 18

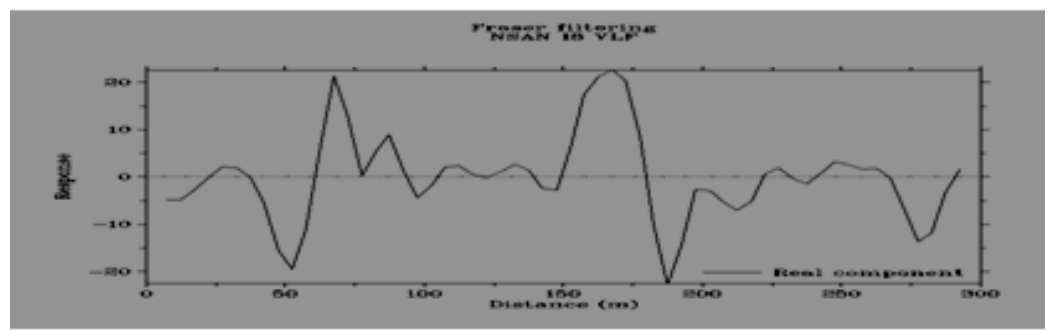

Fig. 56: A plot of filtered in-phase data against distance at location VLF 18 


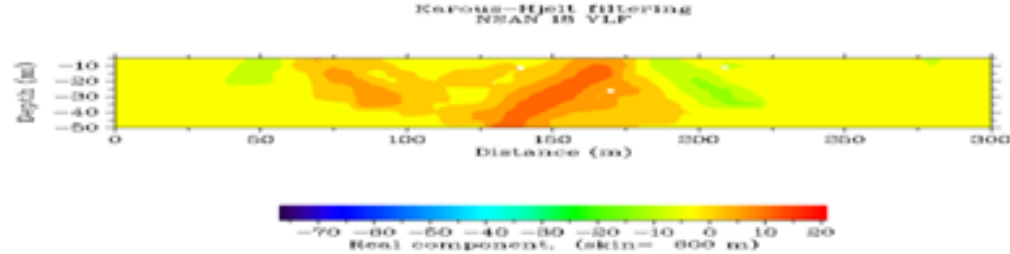

Fig. 57: Current density cross section plot of in-phase data against distances at location VLF 18

At VLF 18, a plot of raw VLF data (Fig.55) and filtered VLF data (Fig.56), show two (2) positive Fraser filter responses. These are located between $60-90 \mathrm{~m}$ and $150-180 \mathrm{~m}$ respectively. The resulting probable fracture zones are located Figure 57 between $60-90 \mathrm{~m}$ and $125-175 \mathrm{~m}$ at a depth extending from 15 $-40 \mathrm{~m}$ and

10 - over 50m respectively. The zones at these location are oriented NW - SE and NE - SW respectively.

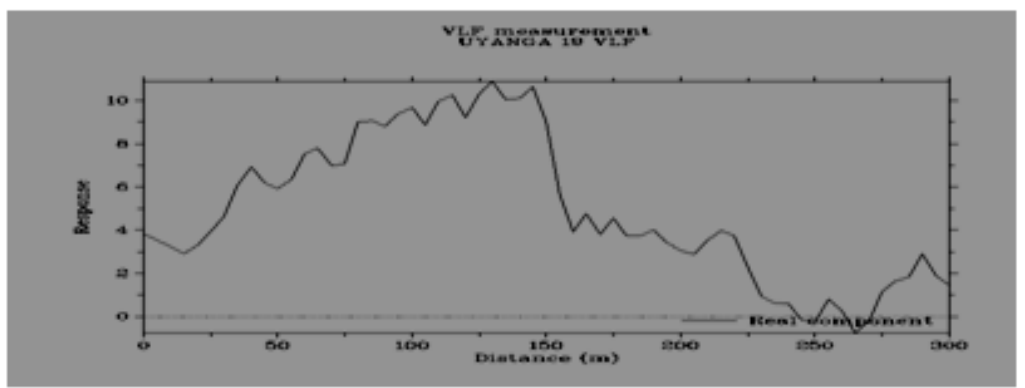

Fig. 58: A plot of unfiltered in-phase data against distance at location VIF 19
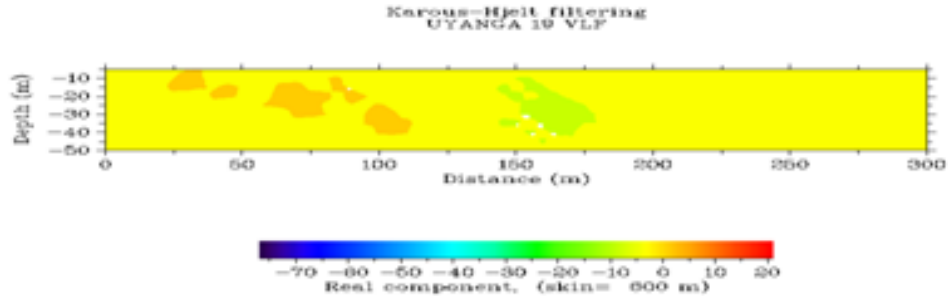

Fig. 59: Current density cross section plot of in-phase data against distances at location VIF 19

The result of VLF data collected and plotted for both raw field data (Fig 58) and filtered data (Fig 59) at location VLF 19 show many positive Fraser responses, giving rise to probable fracture zones located as shown in (Fig 60).

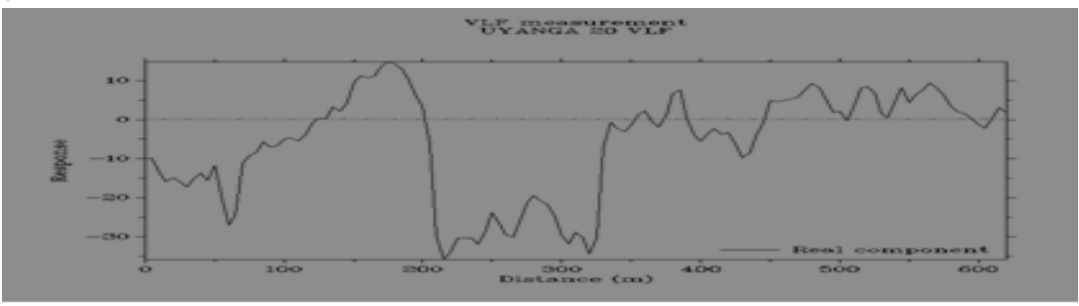

Fig. 60: A plot of unfiltered in-phase data against distance at location VIF 20

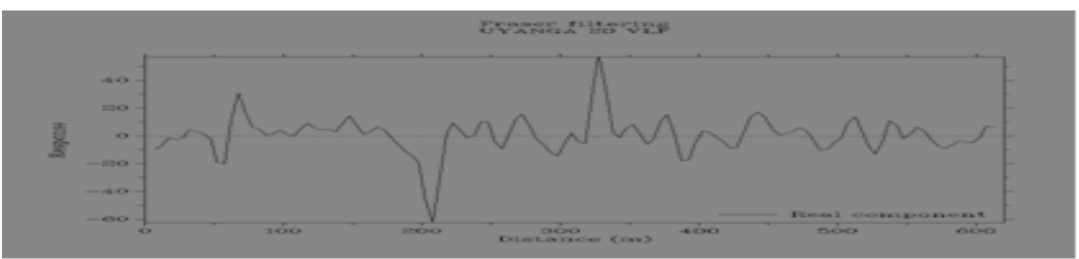

Fig. 61: A plot of unfiltered in-phase data against distance at location VIF 20 


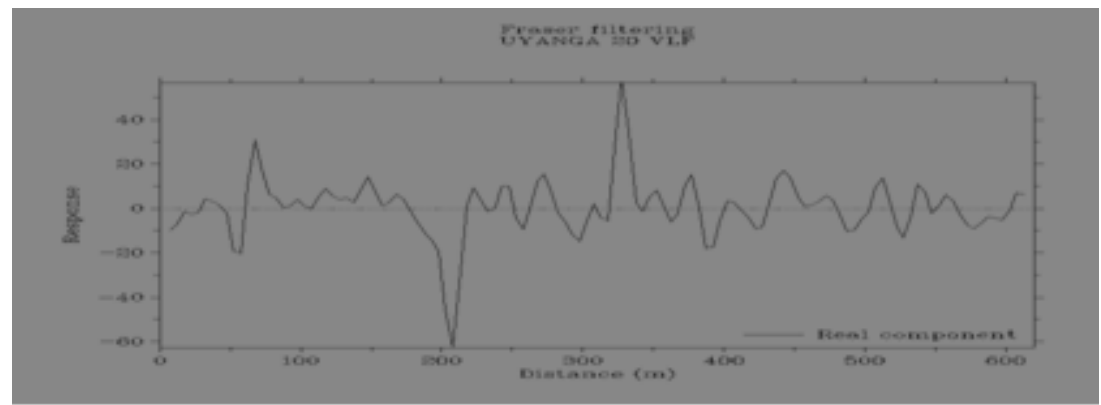

Fig. 62: A plot of filtered in-phase data against distance at location VIF 20

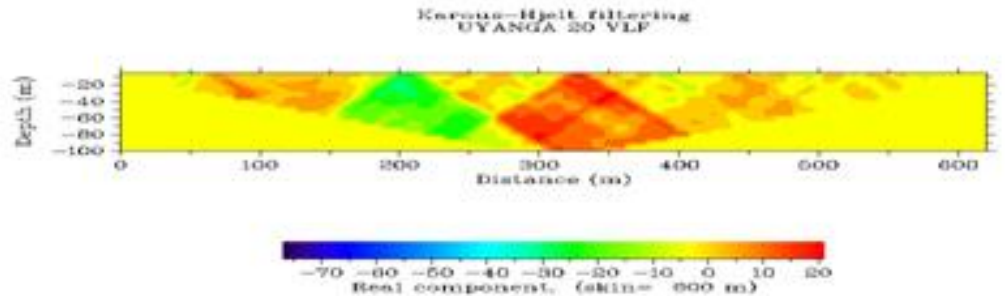

Fig. 63: Current density cross section plot of in-phase data against distances at location VIF 20

At location VLF 20, a plot of raw VLF data (Fig 61) and filtered VLF data (Fig 62) show three (3) prominent positive Fraser responses located between 50 - 150m, $280-380 \mathrm{~m}$ and $440-480 \mathrm{~m}$ respectively. The associated probable fracture zones are located (Fig 63) between $60-140 \mathrm{~m}, 300-360 \mathrm{~m}$ and $450-470 \mathrm{~m}$. These zones are oriented at NW - SE and NE - SW direction respectively.

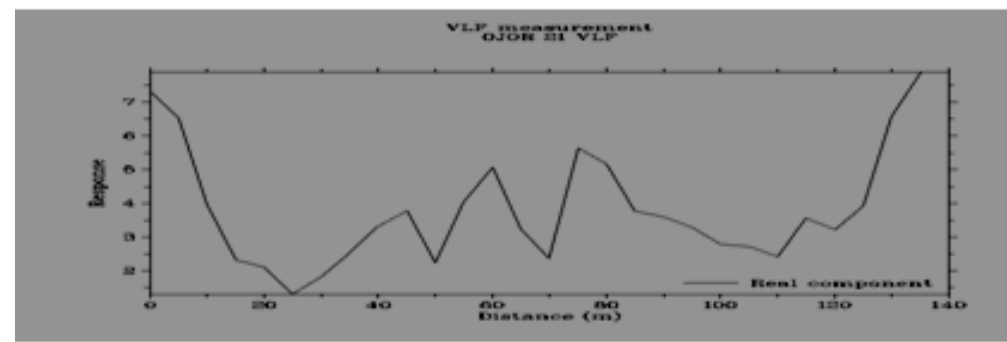

Fig. 64: A plot of unfiltered in-phase data against distance at location VLF 21

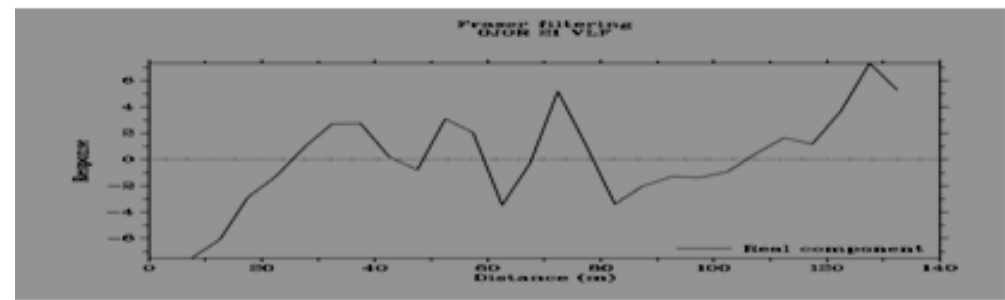

Fig. 65: A plot of filtered in-phase data against distance at location VIF 21

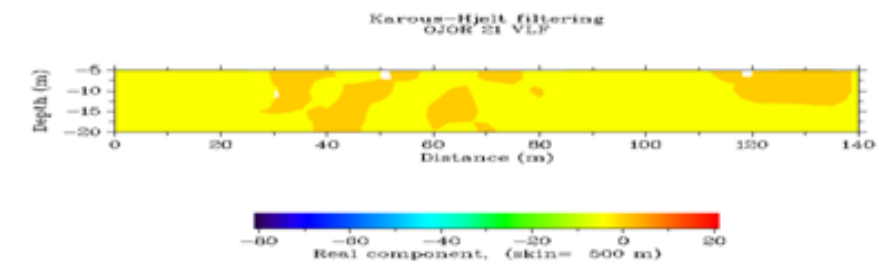

Fig. 66: Current density cross section plot of in-phase data against distances at location VLF 21 
The result of both raw VLF data (Fig. 64) and filtered VLF data (Fig. 65) collected at location VLF 21 show four (4) positive Fraser responses located between $22-40 \mathrm{~m}, 48-58 \mathrm{~m}, 68-78 \mathrm{~m}$ and $110-130 \mathrm{~m}$ respectively. The associated probable fracture zones Figure 66 are located between $30-80 \mathrm{~m}$ and $110-140 \mathrm{~m}$ with depth ranging from $0-15 \mathrm{~m}, 0-$ over $20 \mathrm{~m}$ and $0-12.5 \mathrm{~m}$. These zones are oriented at $\mathrm{NE}-\mathrm{SW}$ and $\mathrm{N}-\mathrm{S}$ direction.

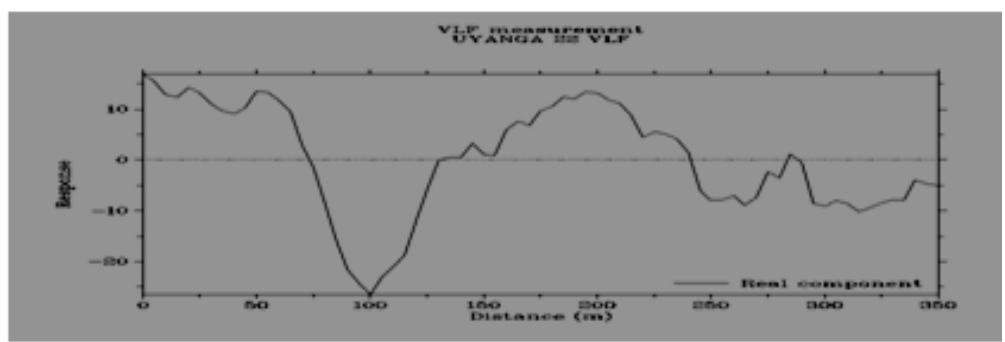

Fig. 67: A plot of unfiltered in-phase data against distance at location VIF 22

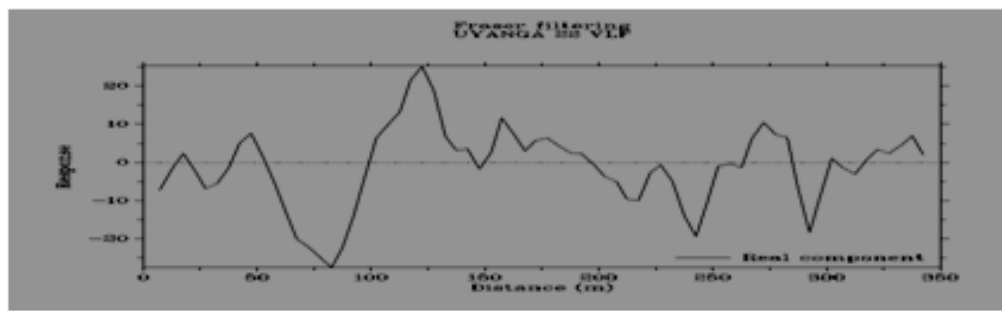

Fig. 68: A plot of filtered in-phase data against distance at location VLF 22

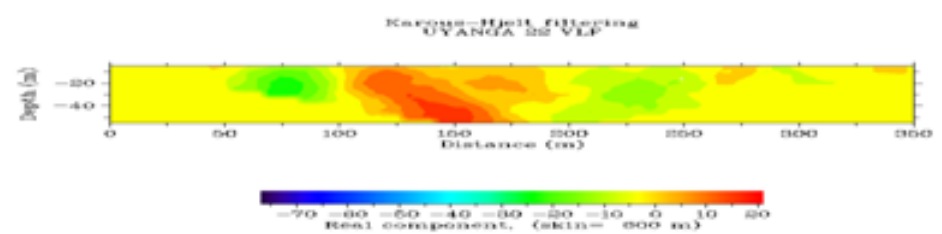

Fig. 69: Current density cross section plot of in-phase data against distances at location VLF 22

At location VLF 22, a plot of raw VLF data (Fig. 67) and filtered VLF data (Fig.68) show two (2) positive Fraser responses. These were located at between $100-200 \mathrm{~m}$ and $260-280 \mathrm{~m}$. The probable fracture zones associated with these positive filter responses are located between $100-190 \mathrm{~m}$ and $265-280 \mathrm{~m}$, Fig 69 at a depth extending from $0-$ over $55 \mathrm{~m}$ and $0-20 \mathrm{~m}$ respectively. The zones had a $\mathrm{NE}-\mathrm{SW}$ and $\mathrm{NW}-\mathrm{SE}$ orientation respectively.

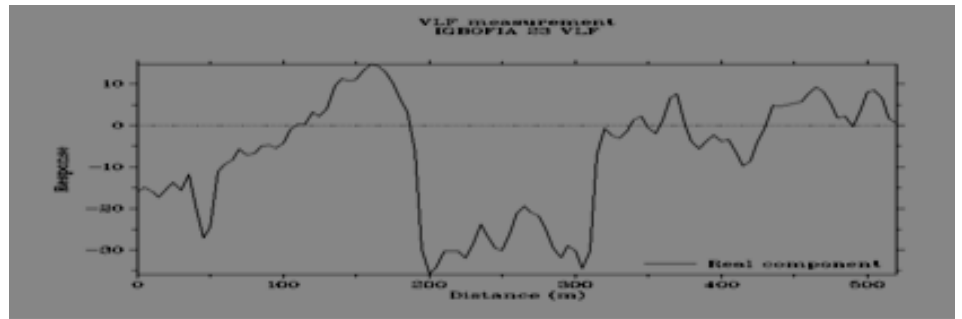

Fig. 70: A plot of unfiltered in-phase data against distance at location VLF 23

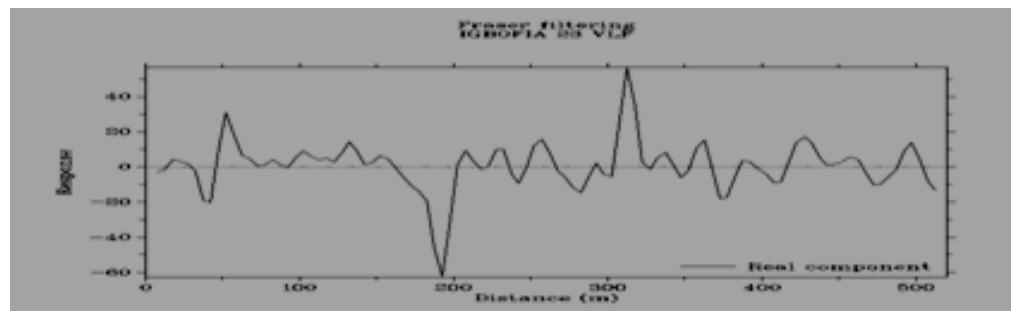

Fig. 71: A plot of filtered in-phase data against distance at location VLF 23 


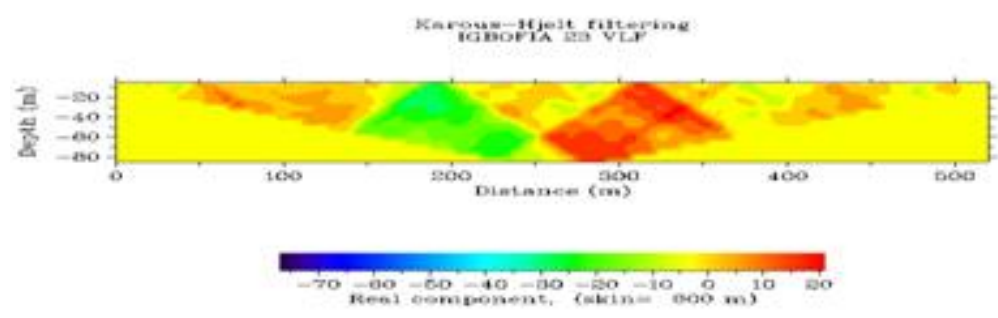

Fig.72: Current density cross section plot of in-phase data against distance

The result of raw VLF data (Fig 70) and filtered data (Fig.71) collected at location VLF 23 show more of positive responses than negative along the traverse. These results in fracture zones located are shown in (Fig.72). These zones are at a depth extending from 0 - over $80 \mathrm{~m}$ oriented at NW - SE and NE - SW direction.

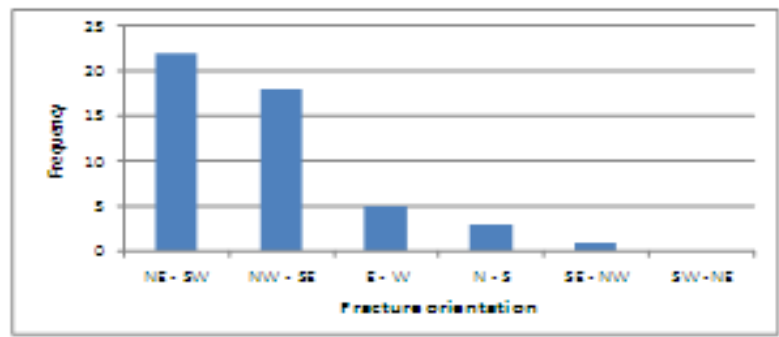

Fig.73: A plot of fracture frequency against fracture orientation

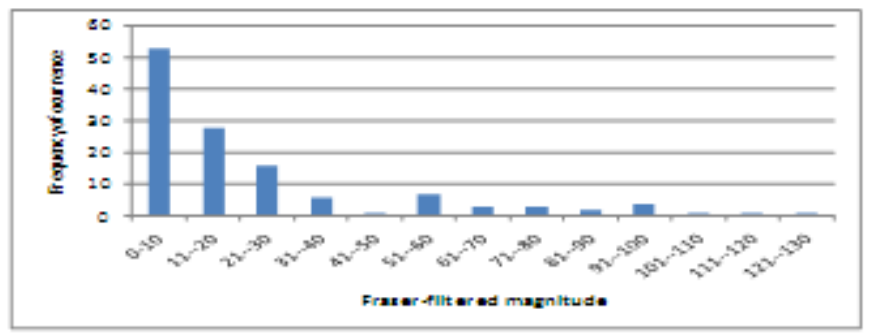

Fig. 74: A plot of Positive Fraser VLF magnitude against frequency of occurrence

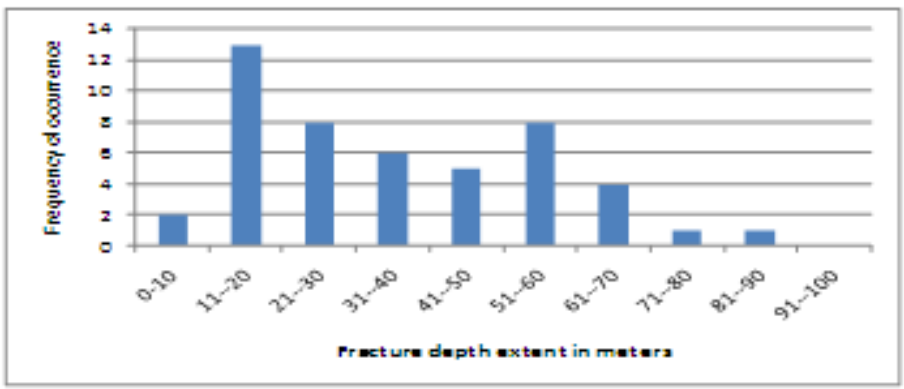

Fig. 75: A plot of fracture depth extent in meters against frequency of occurrence

A plot of the fracture orientation against orientation frequency shows that majority of the fractures were oriented in the NE - SW direction, followed by fractures oriented in the NW - SE direction. This is as shown in the bar chart of (Fig.73). Fractures were also ranked based on the Fraser-filtered VLF magnitude. Fractures with lower positive VLF magnitude were observed to be closer to the surface as compared to those with higher positive VLF magnitude. A plot of positive Fraser-filtered VLF magnitude against frequency of occurrence (Fig.74) shows the distribution of fractures in this respect. Fracture depth distribution is as shown in (Fig.75). The fractures identified were dominantly oriented in NE - SW and NW -SE direction with majority of the fractures at a depth ranging from 0 to $20 \mathrm{~m}$. The ranking of the fracture using positive Fraser-filtered VLF magnitude shows that majority of the fractures had a range of Fraser-filtered VLF magnitude between 0 and 20 indicating that they are shallow seated fractures. 


\section{Conclusion}

The presence of fracture zones with different orientations and depths in all the sampled points in the study area showed that the area is well-fractured and hence has good potentials for groundwater development. This study recommends the drilling of productive and sustainable boreholes at Awi, within College of Education Campus, Mbarakom, $300 \mathrm{~m}$ from the primary School, Ayaebam, $50 \mathrm{~m}$ from the Community Secondary school, Aniking within the settlement area, to a mean depth of $12.5 \mathrm{~m}, 40 \mathrm{~m}, 30 \mathrm{~m}$ and $20 \mathrm{~m}$ respectively. Drilling of boreholes is also recommended to a mean depth of $50 \mathrm{~m}, 40 \mathrm{~m}$ and $30 \mathrm{~m}$ at Akamkpa, $50 \mathrm{~m}$ from the Council Secretariat, Okom Ita, within the settlement area and at Nsan 100m from the quarry site respectively. Similarly, at Uyanga, close to the town hall, Ojor, within the community secondary school and Igbofia borehole drilling is recommended to a mean depth of $60 \mathrm{~m}, 40 \mathrm{~m}$ and $60 \mathrm{~m}$ respectively. Also, this study recommends that since the identified fractures are shallow seated, the study area is not recommended for waste disposal sites to avoid contamination of the groundwater aquifers

\section{References}

[1]. R. D . Barker, C. C White. and J. F. T. Houston Borehole siting in an African accelerated drought relief project. In Wright E. P. and Burgess W. G. E (ed) Hydrogeology of Crystalline Basement Aquifers in Africa. London, Geological Society Special Publication 66, 1992, 183-201.

[2]. R. M Carruthers . and I. F Smith.The use of ground electrical survey methods for sitting water supply boreholes in shallow crystalline basement terrains. In Wright E. P. and Burgess W. G. E (ed) Hydrogeology of Crystalline Basement Aquifers in Africa. London, Geological Society Special Publication, 66, 1992, 203-220.

[3]. T. Dahlin2D resistivity surveying for environmental and engineering Applications. First Break, 14, 1996, 275-28

[4]. A. C .Ekwe, I.N. Nnodu, K.I Ugwubah and O.S Onwuka Estimation of of aquifer hydraulic characteristics of low permeability formation from geosounding data: a case study of Oduma Town, Enugu state. Online Journal of Earth Sciences 4(1), 2010, 19-26

[5]. A. S Ekwere, A. EdetTrace metals in ground and surface waters of the Oban Massif area, SE NigeriaAdvances in Applied Science Research, 3(1), 2012, 312-318

[6]. B. N. Ekwueme, E. E. Nyong and S. W Peters . Geological excursion guidebook to Oban Massif, Calabar flank and Mamfe Embayment, Southeastern Nigeria. Calabar, Dechord Press , 1995, 1-36

[7]. B. N. EkwuemeThe Precambrian geology and evolution of the Southeastern Nigerian basement complex. University of Calabar Press, 2003, p135

[8]. A. M. George, E.E. Okwueze, A. E. Akpanand C. J. Uchegbu Comparative VES studies for the determination of fracture orientation using azimuthal square array Schlumberger array data in Awi within the Oban Massif, S.E Nigeria. Nigerian Journal of Physics, 20 (1), 2008, 136-144.

[9]. E. E. Okwueze Preliminary findings of the groundwater resource potentials from a regional geoelectric survey of the Obudu basement area, Nigeria. Global Journal of Pure and Applied Sciences, 2, 1996, 201-211.

[10]. A. L. Olayinka and A. Weller The inversion of geoelectrical data for hydrogeological application in crystalline basement areas Nigeria.Journal of Applied Geophysics, 37, 1997, 103-115.

[11]. K.O. Ozegi, D.O Isiwele and S.O Azi, Ground water investigation using combined VLF and VES.Journal of the Nigerian Association of Mathematical Physics, 11, 2007, 403-410

[12]. M. PirttijarviKarous-Hjelt and Fraser filtering (KHFFILT) of VLF measurements Version 1.1a.Finland, 2004, University of Oulu

[13]. W. J. Seaton and T.J. Burbey Evolution of two-dimensional resistivity methods in a fractured crystalline terrain.Journal of Applied Geophysics,51, 2002, 21-41.

[14]. S. W. Petters, C. I. Adighije, E. B Essang, and I. E. Ekpo. A Regional Hydrogeological Study of rural water supply options for planning and implementation of phase II rural water programme in Cross River State, Nigeria. Report for Directorate of Rural Development. CRSG, 1989, Nigeria.

[15]. W. E. Medeiros and O. A. L. Lima . A Geophysical investigation for groundwater in crystalline terrains of central Bahia, Brazil. Groundwater, 28, 1990, 518-523. 